() 2020, The Authors. Published by Elsevier Inc. and Fass Inc. on behalf of the American Dairy Science Association ${ }^{\circledR}$. This is an open access article under the CC BY-NC-ND license (http://creativecommons.org/licenses/by-nc-nd/4.0/).

\title{
Quantification of risk factors for bovine viral diarrhea virus in cattle herds: A systematic search and meta-analysis of observational studies
}

\author{
A. M. van Roon, ${ }^{1 *}$ M. Mercat, ${ }^{2}$ G. van Schaik, ${ }^{1,3} \dagger$ M. Nielen, ${ }^{1}$ D. A. Graham,,${ }^{4}$ S. J. More,${ }^{5}$ \\ M. Guelbenzu-Gonzalo, ${ }^{4}$ C. Fourichon, ${ }^{2}$ A. Madouasse, ${ }^{2}$ and I. M. G. A. Santman-Berends ${ }^{1,3}$ \\ ${ }^{1}$ Department of Farm Animal Health, Faculty of Veterinary Medicine, Utrecht University, 3508, TD Utrecht, the Netherlands \\ ${ }^{2}$ INRAE, Oniris, BIOEPAR, 44300, Nantes, France \\ ${ }^{3}$ Royal GD, 7400 AA, Deventer, the Netherlands \\ ${ }^{4}$ Animal Health Ireland, Carrick on Shannon, Co. Leitrim N41 WN27, Ireland \\ ${ }^{5}$ Centre for Veterinary Epidemiology and Risk Analysis, UCD School of Veterinary Medicine, University College Dublin, Belfield, Dublin D04 W6F6, \\ Ireland
}

\section{ABSTRACT}

Bovine viral diarrhea virus (BVDV) is endemic in many parts of the world, and multiple countries have implemented surveillance activities for disease control or eradication. In such control programs, the diseasefree status can be compromised by factors that pose risks for introduction or persistence of the virus. The aim of the present study was to gain a comprehensive overview of possible risk factors for BVDV infection in cattle herds in Europe and to assess their importance. Papers that considered risk factors for BVDV infection in cattle were identified through a systematic search. Further selection of papers eligible for quantitative analysis was performed using a predefined checklist, including (1) appropriate region (i.e., studies performed in Europe), (2) representativeness of the study population, (3) quality of statistical analysis, and (4) availability of sufficient quantitative data. In total, 18 observational studies were selected. Data were analyzed by a random-effects meta-analysis to obtain pooled estimates of the odds of BVDV infection. Metaanalyses were performed on 6 risk factors: herd type, herd size, participation in shows or markets, introduction of cattle, grazing, and contact with other cattle herds on pasture. Significant higher odds were found for dairy herds (odds ratio, $\mathrm{OR}=1.63,95 \%$ confidence interval, CI: 1.06-2.50) compared with beef herds, for larger herds $(\mathrm{OR}=1.04$ for every 10 extra animals in the herd, 95\% CI: 1.02-1.06), for herds that participate in shows or markets $(\mathrm{OR}=1.45,95 \% \mathrm{CI}: 1.10-1.91)$, for herds that introduced cattle into the herd $(\mathrm{OR}=$

Received January 13, 2020

Accepted May 20, 2020.

*Corresponding author: a.m.vanroon@uu.nl

†On behalf of the STOC free consortium: Jörn Gethmann, Carola Sauter-Louis, Jenny Frössling, Estelle Ågren, George Gunn, Madeleine Henry, and Jude Eze.
1.41, $95 \%$ CI: $1.18-1.69)$, and for herds that share pasture or have direct contact with cattle of other herds at pasture $(\mathrm{OR}=1.32,95 \%$ CI: $1.07-1.63)$. These pooled values must be interpreted with care, as there was a high level of heterogeneity between studies. However, they do give an indication of the importance of the most frequently studied risk factors and can therefore assist in the development, evaluation, and optimization of BVDV control programs.

Key words: risk factor, bovine viral diarrhea virus, review, meta-analysis, Europe

\section{INTRODUCTION}

Bovine viral diarrhea (BVD) virus (BVDV) is a pestivirus belonging to the Flaviviridae family (Olafson and Rickard, 1947). It is one of the most common viral diseases in cattle and endemic in many parts of the world (Scharnböck et al., 2018). Bovine viral diarrhea virus is mainly spread by persistently infected (PI) cattle, which were infected in utero between 40 and $120 \mathrm{~d}$ of gestation and shed large amounts of virus into the environment after birth (McClurkin et al., 1984). Bovine viral diarrhea virus can be transmitted directly through nose-to-nose contact between cattle or indirectly through contaminated materials (Tråvén et al., 1991; Niskanen and Lindberg, 2003). Infections with BVDV can lead to respiratory and reproductive issues, causing major economic losses (Houe, 2003). Many European countries have implemented BVDV control or eradication programs, and some have already successfully eradicated the virus or reached a herd-level prevalence below 1.5\% (Sweden, Norway, Finland, Denmark, Germany, Austria, Switzerland, and Ireland; Nuotio et al., 1999; Bitsch et al., 2000; Hult and Lindberg, 2005; Rikula et al., 2005; Rossmanith et al., 2010; Presi et al., 2011; Norström et al., 2014; Foddai et al., 2016; AHI, 2019). Within those control programs, animals, herds, 
regions, or the country are ascribed a BVDV-free status that is subsequently monitored.

The probability that a herd categorized as free within a control program is truly free of infection will be influenced by risk factors for introduction of the virus (i.e., the probability that the virus is introduced or reintroduced into the herd between test moments) and factors that cause delayed detection of the virus after introduction or reintroduction (i.e., the probability that the virus had been introduced but not yet detected). The effectiveness of surveillance relies on an understanding of these risk factors. Delayed detection of the virus can be associated with herd management, control program design (e.g., test population, test frequency, sample size, test validity), and test performance. Risk factors for introduction depend on the contact structure between herds, such as purchase or contact with cattle from neighboring herds. The introduction of purchased animals is a well-known risk factor. However, an overview of the magnitude of the risk, and of country-level differences, is lacking.

Risk factors for introduction and delayed detection of BVDV are not easily studied in isolation due to the difficulty of determining exactly when the virus is introduced into a herd. Risk factors for the presence of infection are more often reported (e.g., Graham et al., 2013; Byrne et al., 2017; Amelung et al., 2018) and could serve as a proxy for introduction and delayed detection. In this study, we have conducted a systematic literature search, seeking to gain a comprehensive overview of possible risk factors for the presence of BVDV infection in cattle herds in Europe. We aimed to assess the importance of the most frequently studied risk factors and, depending on study quality and the availability of quantitative data, to perform meta-analyses to obtain pooled values. This information is critical for the development, evaluation, and optimization of BVDV control programs. Control program managers can list and prioritize risk factors in their country based on the pooled values or choose the results from countries most comparable with their situation.

\section{MATERIALS AND METHODS}

This systematic review was reported according to the Preferred Reporting Items for Systematic Reviews and Meta-Analyses (PRISMA) guidelines (Moher et al., 2009) with the PRISMA 2009 Checklist (Supplemental File S1, https://doi.org/10.3168/jds.2020-18193).

\section{Search Strategy}

Three databases (PubMed, CAB Abstracts, and Scopus) were interrogated using the search terms defined below. The final complete data search in all 3 databases was performed on September 21, 2018. An additional search was performed after the full-text screening and before data analysis on July 15, 2019. This additional search was performed only in PubMed because Scopus and $\mathrm{CAB}$ Abstracts do not allow selection for specific publication dates, only per year.

The research questions include 4 key aspects: BVDV, risk factors, introduction, and delayed detection. The BVDV search terms included the following: BVD, BVDV, bovine viral diarrh(o)ea, bovine viral diarrh(o) ea, and bovine viral diarrh(o)ea virus. Risk factor search terms included the following: risk factor, purchase, import, trade, market, grazing, nose-to-nose contact, direct contact, over the fence contact, density, contact structure, herd, herd size, seasonal calving, calving pattern, housing system, management, biosecurity, vaccination, artificial insemination, embryo transfer, PI, persistent infection, and persistently infected. Introduction search terms included the following (where * indicates a wildcard): introduction, pathway, epidemio*, incidence, prevalence, and contamin*. Finally, delayed detection search terms included the following: diagnostic test, persist*, delayed detection, test strategy, test scheme, test performance, test characteristics, sensitivity, control program*, eradication program*, surveillance, false negative, free, freedom, transmission, and spread. The full electronic search strategy is included in Supplemental File S2 (https://doi.org/10.3168/jds.2020-18193).

\section{Study Selection}

Studies published in peer-reviewed journals with full text available were considered. They reported either risk factors for introduction of BVDV in cattle herds or risk factors for the presence of BVDV from which risk factors for introduction could be inferred. During the initial screening, studies were also included from which risk factors for delayed detection could be inferred (e.g., studies reporting test characteristics). In a later stage, it was decided to focus on risk factors for introduction and presence of BVDV to narrow down the search. Only studies with a cross-sectional, cohort, case-control, or randomized controlled trial study design were considered. Languages that were accepted were English, Dutch, French, Spanish, and German. Studies published since 1980 were included to focus on modern farm management systems.

The search in PubMed, CAB Abstracts, and Scopus was carried out by one researcher (AvR). The researcher imported all references into the online systematic review management tool Covidence (Veritas Health Innovation, Melbourne, VIC, Australia). In Covidence, duplicates were deleted automatically or following a 
manual review. Two researchers (AvR and MM) both went independently through the following consecutive phases of the review: (1) screening titles and abstracts based on the inclusion criteria described above, and (2) reviewing full-text articles based on the inclusion criteria described above. After these review steps, conflicting opinions on papers were discussed with the other co-authors to reach consensus on inclusion or exclusion.

All full-text studies that were selected based on the inclusion criteria were further assessed for their appropriateness for meta-analyses by one researcher (AvR). This was done using the approach presented in Table 1. This checklist consists of 4 questions regarding internal validity (how well is the study conducted?) and external validity (generalizability). As no generic tool is available for appraisal of observational studies for meta-analysis (Sanderson et al., 2007), we created our own checklist with relevant checkpoints based on our own observations and in alignment with the methods used in previous studies (National Institutes of Health, 2014; Downes et al., 2016).

On several occasions, multiple studies were described in a single paper (so-called split studies) - for example, if a risk factor study was performed on different outcome variables (e.g., antibody or virus) or different types of cattle (e.g., beef or dairy) or if more than one final risk factor model was developed. We decided to include both split studies where beef and dairy herds were analyzed separately because these risk factor analyses were performed on different populations (e.g., Gates et al., 2013, 2014). When studies concluded with more than one final model, the model indicated by the authors as best describing the data was included. If no choice was made between the different final models, we selected the model that took into account the full data set. Risk factor analyses performed on subsets of the data were excluded.

\section{Data Collection}

Data were extracted from all selected studies using an Excel (Microsoft Corp., Redmond, WA) form that was prepared in advance. Data were extracted by one researcher $(A v R)$ and checked by the other researcher (MM). A pilot test of the Excel form was conducted by these 2 researchers working together on 3 selected papers to increase uniformity in extracting the data.

For each selected study, detailed data were extracted regarding study type, location, size of the study population, diagnostic tests used, risk factors studied in univariable and multivariable analysis, the effect size (odds ratio, OR; relative risk), confidence intervals, and the statistical analysis that was performed.

\section{Meta-Analysis}

All risk factors from the studies that were selected for quantitative analysis were listed and combined into groups of similar risk factors. Per group, OR reported in at least 2 independent studies were analyzed by a random-effects meta-analysis to obtain pooled estimates of the odds of BVDV infection. In some cases, variables first had to be restructured to be able to include them in the meta-analysis. For example, this was the case with introduction of cattle where we wanted to combine variables with "yes introduction" versus "no introduction" with categorical variables where different numbers of introduced cattle were compared with zero introduction. In this case, we first performed a within-study fixed-effects meta-analysis on the different categories of this variable to obtain a summary estimate across all categories. This summary estimate could subsequently be included in the overall meta-analysis for introduction of cattle.

Table 1. Checklist study appraisal for quantitative analysis

\begin{tabular}{|c|c|c|}
\hline Item & Not appropriate for meta-analysis & Appropriate for meta-analysis \\
\hline \multicolumn{3}{|l|}{ External validity } \\
\hline $\begin{array}{l}\text { 1. Is the cattle production system } \\
\text { comparable with the European } \\
\text { situation? }\end{array}$ & Studies were performed outside of Europe. & Studies were performed in Europe. \\
\hline $\begin{array}{l}\text { 2. Are the selected animals or herds } \\
\text { representative of the target population } \\
\text { (commercial cattle herds in Europe)? }\end{array}$ & $\begin{array}{l}\text { No, with high possibility of selection bias. } \\
\text { Animals or herds are selected purposively. }\end{array}$ & $\begin{array}{l}\text { Yes, with low or medium possibility of selection } \\
\text { bias. Animals or herds are selected randomly or } \\
\text { in a way that represents the target population. }\end{array}$ \\
\hline \multicolumn{3}{|l|}{ Internal validity } \\
\hline $\begin{array}{l}\text { 3. Was the unit of interest appropriate for } \\
\text { a herd-level risk factor study? }\end{array}$ & $\begin{array}{l}\text { Animal-level data were used without } \\
\text { correction for within-herd correlation. }\end{array}$ & $\begin{array}{l}\text { Herd-level data or animal-level data that were } \\
\text { corrected for clustering were used. }\end{array}$ \\
\hline 4. Are quantitative data available? & $\begin{array}{l}\text { No, there are only descriptive studies, or } \\
\text { some quantitative data but no odds ratios } \\
\text { or data from which odds ratios could be } \\
\text { derived. }\end{array}$ & $\begin{array}{l}\text { Yes, there are quantitative data (odds ratios } \\
\text { or data to derive odds ratios) of univariable or } \\
\text { multivariable analysis. }\end{array}$ \\
\hline
\end{tabular}


A random-effects approach is considered the default method in meta-analysis of observational studies (Mueller et al., 2018). This approach accounts for the fact that the study effect estimates are not drawn from a single population, which would be the case when using a fixed-effects approach (Harrer et al., 2019). The random-effects models were fitted in a 2-step approach. First, between-study variance, represented by the distribution of the true study effects, was estimated with the DerSimonian-Laird approach. Then, weights were assigned to all included studies based on the inverse of the variance as in general the population size between observational studies is not equal and pooled OR were estimated (Viechtbauer, 2010). In this process, the OR and their $95 \%$ confidence intervals (CI) as reported in the individual studies were log-transformed; therefore, due to rounding errors, the $95 \%$ CI in our results might differ slightly from the data reported in the individual studies. Preferably, adjusted OR that resulted from multivariable analysis were used. When no multivariable results were available, crude OR that resulted from univariable analysis were included. If no OR were available but frequencies were reported, OR were calculated. In each forest plot, the univariable results were marked. Also, subanalyses were performed in which univariable and multivariable results were analyzed separately.

Heterogeneity between studies was studied by the $\mathrm{I}^{2}$ statistic. The $\mathrm{I}^{2}$ statistic shows what proportion of the variance is due to heterogeneity in true effects rather than sampling error (Borenstein et al., 2017). To identify studies with the greatest influence on the results, an influential case analysis was performed with cut-off values proposed by Viechtbauer and Cheung (2010). The studies indicated as outliers were marked in each forest plot. The change in the summary estimates and $\mathrm{I}^{2}$ statistic when retaining or removing outliers was of minor importance. Publication bias could not be properly assessed due to the low number of studies included in our meta-analyses $(\mathrm{n}<10$; Higgins et al., 2019). Funnel plots were checked for asymmetry, with some indication of publication bias, but these plots are not reported as it was not possible to determine whether this was by chance or real asymmetry due to the low number of studies. Meta-analyses were performed using $\mathrm{R}$ statistical software (R Core Team, 2019) and the metafor package (Viechtbauer, 2010).

\section{RESULTS}

\section{Literature Search}

The original searches revealed 12,028 papers, of which ultimately 259 papers were full-text screened and nar- rowed down to 51 papers (Figure 1). Based on Table 1, all 51 papers were screened for their appropriateness for quantitative analyses (Supplemental File S3, https:// doi.org/10.3168/jds.2020-18193). Eventually, 18 papers (20 studies) were selected for inclusion in the metaanalysis (Table 2).

\section{Overview of Risk Factors}

All risk factors that were studied in the final 18 papers were grouped into 6 risk factor categories: (1) herd and animal characteristics, (2) cattle movement, (3) reproduction, (4) neighborhood risk, (5) farm management and biosecurity, and (6) diagnostic testing and control programs.

\section{Description of Risk Factors}

Herd and Animal Characteristics. Herd and animal characteristics that were studied included milk yield, sex, age, infection with other pathogens, mortality, region, herd type, and herd size. Of all herd characteristics, variables describing herd size, herd type, and region were included most frequently (Table 3 ).

No further analysis could be performed on milk yield and sex as for both there was only 1 study with quantitative data. Age was included as a categorical variable in 2 studies (Mainar-Jaime et al., 2001; Hanon et al., 2018), both with higher OR for the presence of BVD antibodies in higher age classes. However, the age categories within those 2 studies were not comparable and therefore were unsuitable for meta-analysis. Infection with other pathogens associated with BVD infection was considered in 3 studies but could not be compared because different pathogens were studied (i.e., Neospora caninum, bovine herpes virus-1, and bovine tuberculosis). Mortality was considered in 5 studies, but as this was regarded more an outcome than a risk factor for BVDV, it was not included in the meta-analysis. Finally, region was not included in the meta-analysis even though this was one of the most studied risk factors within the herd and animal characteristics group. Because different regions were included in different studies, comparison of the risk estimates between regions was impossible. Nevertheless, most studies found significant differences between regions, which makes this an important risk factor to consider. Meta-analysis was performed on herd type and herd size.

Cattle Movement. Movement characteristics that were studied included introduction of cattle, cattle shows or markets, and other movements (e.g., sale and exchange of calves). Of all cattle movement risk factors, variables describing introduction of cattle into a herd 


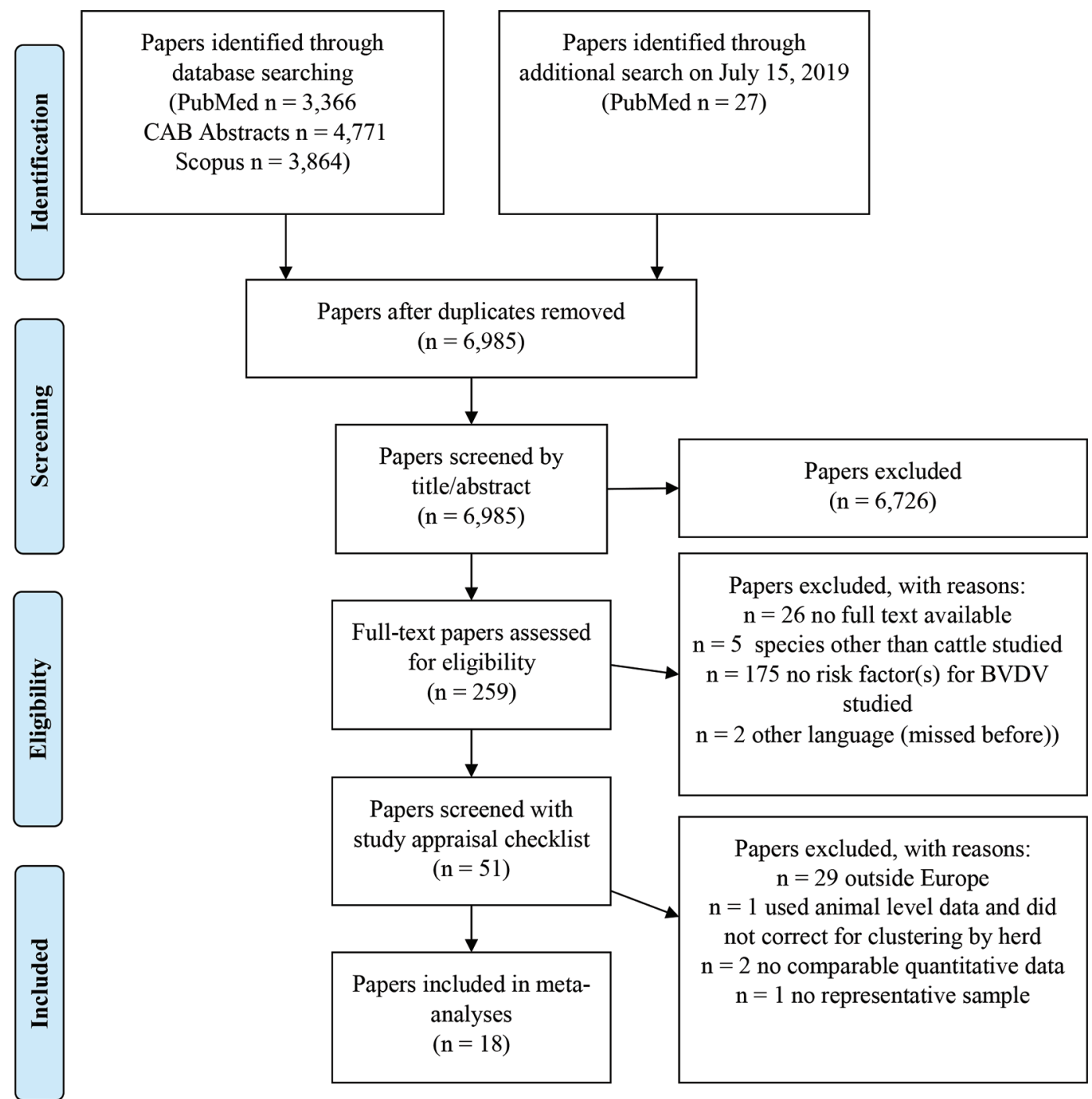

Figure 1. Flow diagram showing the total number of papers identified and excluded per stage of the selection process. At the eligibility stage, we decided to exclude papers that were initially selected for delayed detection. The 175 "no risk factor(s) for BVDV studied" papers were about BVDV test characteristics. BVDV = bovine viral diarrhea virus.

were included most frequently (Table 4). We considered studies on introduction of cattle into a herd and on purchase, where the latter assumes monetary transfer, which is not necessarily the case with introduction. In this paper, we use "introduction," which also covers purchase.

Other types of cattle movements were studied by Valle et al. (1999) and Amelung et al. (2018). Valle et al. (1999) looked at "other animal traffic," combining mainly exchange of calves and sharing of cattle housing with other farmers during summer. They found a very high OR of 28.60 (95\% CI: 3.23-252.22). Amelung et al. (2018) studied sale of cattle, which was not comparable with the cattle movement studied in Valle et al.
(1999). Meta-analysis was performed on cattle shows or markets and introduction of cattle.

Reproduction. Reproduction variables that were studied included AI versus use of bulls and calving pattern (Table 5). The number of studies was too small or the definition of the variables varied too much between studies to enable a meta-analysis to be conducted.

Variables regarding AI or the use of bulls were included only in univariable analyses. In Amelung et al. (2018), higher but nonsignificant OR were found for BVD infection in herds with $\mathrm{AI}(\mathrm{OR}=1.28,95 \% \mathrm{CI}$ : 0.96-1.71) compared with herds without AI but also in herds with a bull for insemination $(\mathrm{OR}=1.17,95 \%$ CI: 0.93-1.48) compared with herds without a bull. 
van Roon et al.: RISK FACTORS FOR BOVINE VIRAL DIARRHEA VIRUS

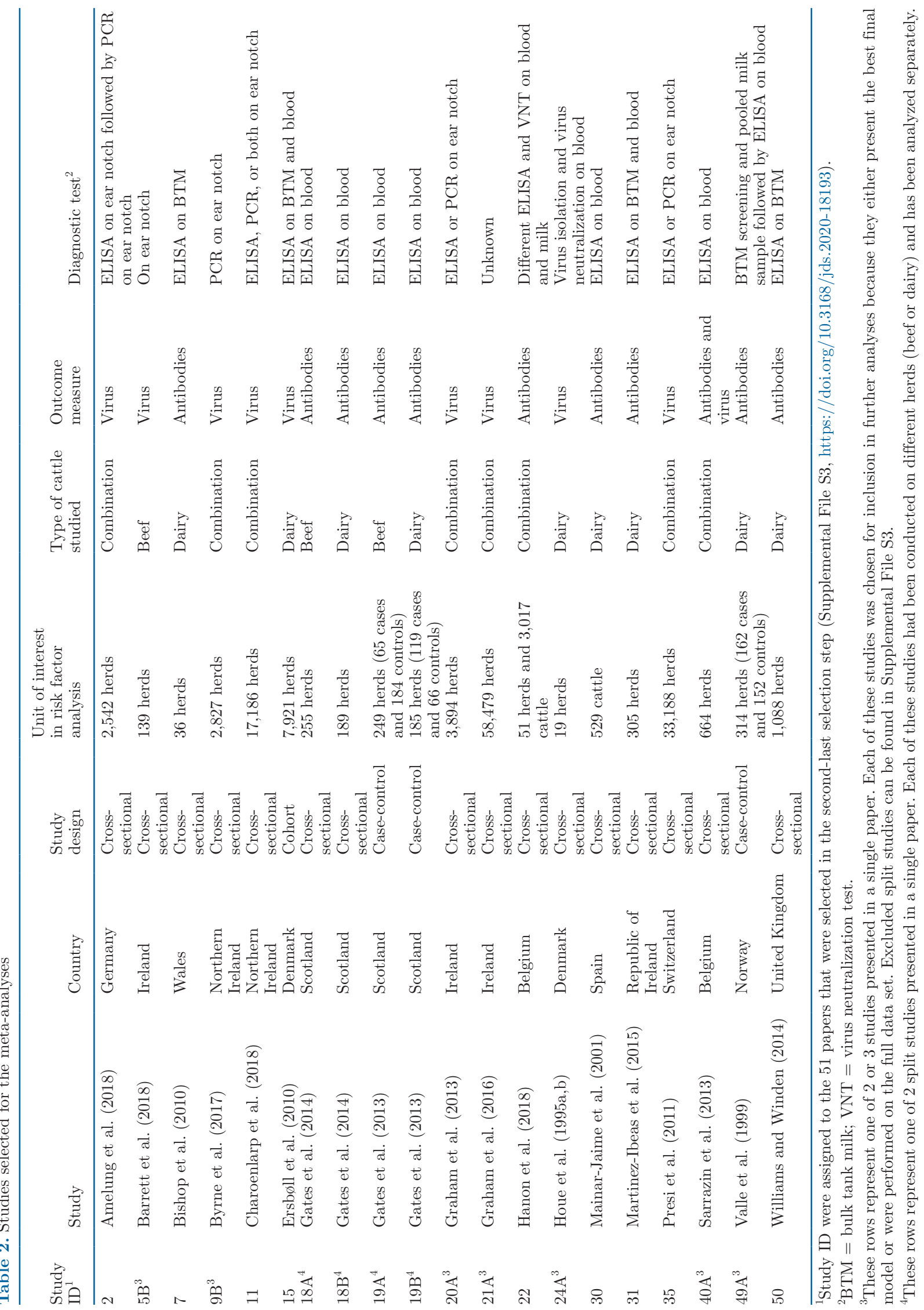


Table 3. Overview of the number of risk factor studies (out of the selected 18 papers on 20 studies) that included herd and animal characteristics and the availability of quantitative data

\begin{tabular}{lcclr}
\hline Factor & $\begin{array}{c}\text { No. of } \\
\text { studies }\end{array}$ & $\begin{array}{c}\text { No. of } \\
\text { variables }\end{array}$ & Study ID ${ }^{1}$ & $\begin{array}{c}\text { No. of variables } \\
\text { with quantitative data }\end{array}$ \\
\hline Milk yield & 2 & 2 & 2,30 & 1 \\
Sex & 1 & 1 & 22 & 1 \\
Age & 2 & 2 & 22,30 & 2 \\
Infection with other pathogens & 3 & 6 & $5 \mathrm{~B}, 9 \mathrm{~B}, 30$ & 3 \\
Mortality & 5 & 7 & $5 \mathrm{~B}, 9 \mathrm{~B}, 20 \mathrm{~A}, 30,35$ & 5 \\
Region $^{2}$ & 8 & 8 & $2,9 \mathrm{~B}, 11,15,20 \mathrm{~A}, 21 \mathrm{~A}, 30,31$ & 7 \\
Herd type $^{2}$ & 9 & 11 & $2,9 \mathrm{~B}, 11,20 \mathrm{~A}, 21 \mathrm{~A}, 22,30,35,40 \mathrm{~A}$ & 9 \\
& 14 & 20 & $2,5 \mathrm{~B}, 9 \mathrm{~B}, 11,15,20 \mathrm{~A}, 21 \mathrm{~A}, 22,24 \mathrm{~A}, 30,31$, & 13 \\
\hline
\end{tabular}

${ }^{1}$ Study ID were assigned to the 51 papers that were selected in the second-last selection step (see Supplemental File S3, https://doi.org/10.3168/ jds.2020-18193).

${ }^{2}$ Included in the meta-analysis.

Table 4. Overview of the number of risk factor studies (out of the selected 18 papers on 20 studies) that included cattle movement variables and the availability of quantitative data

\begin{tabular}{lcclr}
\hline Factor & $\begin{array}{c}\text { No. of } \\
\text { studies }\end{array}$ & $\begin{array}{c}\text { No. of } \\
\text { variables }\end{array}$ & Study ID ${ }^{1}$ & $\begin{array}{c}\text { No. of variables } \\
\text { with quantitative data }\end{array}$ \\
\hline Other movement $_{\text {Cattle shows or markets }^{2}}$ & 2 & 2 & 2,35 \\
Introduction of cattle $^{2}$ & 5 & 5 & $2,19 \mathrm{~A}, 19 \mathrm{~B}, 22,35$ & 2 \\
& 17 & 62 & $2,5 \mathrm{~B}, 7,9 \mathrm{~B}, 18 \mathrm{~A}, 18 \mathrm{~B}, 19 \mathrm{~A}, 19 \mathrm{~B}, 20 \mathrm{~A}, 21 \mathrm{~A}, 22$, \\
\end{tabular}

${ }^{1}$ Study ID were assigned to the 51 papers that were selected in the second-last selection step (see Supplemental File S3, https://doi.org/10.3168/ jds.2020-18193).

${ }^{2}$ Included in the meta-analysis.

Table 5. Overview of the number of risk factor studies (out of the selected 18 papers on 20 studies) that included reproduction variables and the availability of quantitative data

\begin{tabular}{lcclc}
\hline Factor & $\begin{array}{c}\text { No. of } \\
\text { studies }\end{array}$ & $\begin{array}{c}\text { No. of } \\
\text { variables }\end{array}$ & Study ID $^{1}$ & $\begin{array}{c}\text { No. of variables } \\
\text { with quantitative data }\end{array}$ \\
\hline Calving pattern & 1 & 1 & 50 & 1 \\
AI/use of bulls & 3 & 4 & $2,7,50$ & 3 \\
\hline
\end{tabular}

${ }^{1}$ Study ID were assigned to the 51 papers that were selected in the second-last selection step (see Supplemental File S3, https://doi.org/10.3168/jds.2020-18193).

Table 6. Overview of the number of risk factor studies (out of the selected 18 papers on 20 studies) that included neighborhood variables and the availability of quantitative data

\begin{tabular}{lcclc}
\hline Factor & $\begin{array}{c}\text { No. of } \\
\text { studies }\end{array}$ & $\begin{array}{c}\text { No. of } \\
\text { variables }\end{array}$ & Study ID & $\begin{array}{c}\text { No. of variables } \\
\text { with quantitative data }\end{array}$ \\
\hline Farm fragmentation & 1 & 1 & $20 \mathrm{~A}$ & 1 \\
Environment & 1 & 4 & 11 & 4 \\
Cattle density & 6 & 9 & $11,15,19 \mathrm{~A}, 19 \mathrm{~B}, 21 \mathrm{~A}, 30$ & 7 \\
BVD $^{2}$-positive neighbor herds & 3 & 11 & $11,15,21 \mathrm{~A}, 20 \mathrm{~A}, 49 \mathrm{~A}$ & 8 \\
Contact with other animal species $_{\text {Pasture }^{3}}$ & 5 & 10 & $2,19 \mathrm{~A}, 19 \mathrm{~B}, 2 \mathrm{~B}, 22,24 \mathrm{~A}, 35,49 \mathrm{~A}$ & 8 \\
\hline
\end{tabular}

${ }^{1}$ Study ID were assigned to the 51 papers that were selected in the second-last selection step (Supplemental File S3, https://doi.org/10.3168/ jds.2020-18193).

${ }^{2}$ Bovine viral diarrhea.

${ }^{3}$ Included in the meta-analysis. 
Table 7. Overview of the number of risk factor studies (out of the selected 18 papers on 20 studies) that included farm management and biosecurity variables and the availability of quantitative data

\begin{tabular}{lcclc}
\hline Factor & $\begin{array}{c}\text { No. of } \\
\text { studies }\end{array}$ & $\begin{array}{c}\text { No. of } \\
\text { variables }\end{array}$ & Study ID & $\begin{array}{c}\text { No. of variables } \\
\text { with quantitative data }\end{array}$ \\
\hline Other biosecurity & 2 & 2 & $19 \mathrm{~A}, 19 \mathrm{~B}$ & 2 \\
Hygiene & 2 & 2 & $19 \mathrm{~A}, 19 \mathrm{~B}$ & 2 \\
Quarantine & 3 & 3 & $7,19 \mathrm{~A}, 19 \mathrm{~B}$ & 2 \\
Mixed beef and dairy farm & 3 & 3 & $19 \mathrm{~A}, 19 \mathrm{~B}, 49 \mathrm{~A}$ & 2 \\
Vaccination & 3 & 4 & $22,31,40 \mathrm{~A}$ & 4 \\
Housing & 2 & 4 & 2,22 & 4 \\
Shared equipment & 3 & 5 & $19 \mathrm{~A}, 19 \mathrm{~B}, 49 \mathrm{~A}$ & 8 \\
People on farm & 2 & 8 & $19 \mathrm{~A}, 19 \mathrm{~B}$ & 4 \\
\hline
\end{tabular}

${ }^{1}$ Study ID were assigned to the 51 papers that were selected in the second-last selection step (Supplemental File S3, https://doi.org/10.3168/jds.2020-18193).

Williams and Winden (2014) compared herds with a bull present on the farm with herds with AI only and found that herds with a bull present on the farm had higher but nonsignificant odds of infection with BVD $(\mathrm{OR}=1.16,95 \%$ CI: 0.90-1.49). Calving pattern was found only once in a univariable risk factor analysis and showed higher odds of infection $(\mathrm{OR}=1.80,95 \% \mathrm{CI}$ : 1.22-2.67) in herds with year-round calving compared with seasonal calving (Williams and Winden, 2014).

Neighborhood Risk. Variables related to neighborhood risk included farm fragmentation, environment, cattle density, BVD-positive neighbor herds, contact with other animal species, and pasture. Of all neighborhood risk factors, variables describing cattle density, contact with other animal species, and pasture were included most frequently (Table 6).

Farm fragmentation (number of individual noncontiguous parcels of land associated with the herd) and environment (i.e., natural grassland, forest) were both studied only once; therefore, no meta-analysis could be performed. Cattle density and BVD-positive neighbor herds were studied more frequently but in such different ways that meta-analysis was not possible. Both variables describe in different ways the distance to (positive) neighboring herds or the number of (positive) neighboring herds contiguous to the farm or in a 5 - or $10-\mathrm{km}$ radius. They are continuous or categorical. Most studies showed higher odds of BVD infection when the distance to (positive) neighbors is shorter, when there are more (positive or unknown status) neighbors close by, or when BVD-positive animals are retained for a longer period. One study found that seropositivity increased with a larger distance (in $\mathrm{km}$ ) to the closest dairy farm (Mainar-Jaime et al., 2001). Variables regarding contact with other animal species included the presence of, contact with, close proximity of, or grazing with sheep, pigs, deer, or wildlife. No meta-analysis could be performed on contact with other animal species.
Farm Management and Biosecurity. Variables included were quarantine, vaccination, mixed beef and dairy farm, type of housing, shared equipment, people on farm, and other biosecurity. None of these variables were suitable for meta-analysis because of noncomparable definitions or the low number of studies in which these factors were studied (Table 7).

Most farm management and biosecurity variables were studied by Gates et al. (2013). They studied the relative influence of cattle movements, local spread, and biosecurity on BVDV seropositivity. The variables we included in the farm management and biosecurity group were not exactly identical to the classification of biosecurity variables in the study of Gates et al. (2013), but especially for beef herds, cattle movement had the greatest influence on BVDV seropositivity. Also, in the other studies included in Table 7, most biosecurity variables were nonsignificant.

Diagnostics Testing and Control Programs. Multiple papers studied variables related to diagnostic testing and control programs that we grouped into BVDV testing, farmer behavior, control program, and other (Table 8). However, either the number of studies was too small or the definition of these variables varied too much between studies to enable a meta-analysis to be conducted.

Within the diagnostic testing and control programs group, BVDV testing was studied most. Examples of variables studied are the total number of BVDV tests undertaken and detection of PI animals in the past. One study (Amelung et al., 2018) found that herds that participated in a control program has slightly higher odds $(\mathrm{OR}=1.28,95 \% \mathrm{CI}: 1.01-1.64)$ for BVDV infection in univariable analysis than herds that do not participate. One of the studies looking at farmer behavior showed that the age of farmers was associated with the BVD status. Herds of farmers younger than $40 \mathrm{yr}$ were more often infected than herds of farmers between 50 and $60 \mathrm{yr}$. 
Table 8. Overview of the number of risk factor studies (out of the selected 18 papers on 20 studies) that included diagnostic testing and control program variables and the availability of quantitative data

\begin{tabular}{lcclc}
\hline Factor & $\begin{array}{c}\text { No. of } \\
\text { studies }\end{array}$ & $\begin{array}{c}\text { No. of } \\
\text { variables }\end{array}$ & Study ID $^{1}$ & $\begin{array}{c}\text { No. of variables } \\
\text { with quantitative data }\end{array}$ \\
\hline Other & 3 & 3 & $11,40 \mathrm{~A}, 21 \mathrm{~A}$ & 2 \\
Farmer (behavior) & 2 & 4 & $2,49 \mathrm{~A}$ & 3 \\
Control program & 3 & 3 & $2,11,22$ & 3 \\
BVDV testing & 7 & 8 & $9 \mathrm{~B}, 19 \mathrm{~A}, 19 \mathrm{~B}, 20 \mathrm{~A}, 30,31,40 \mathrm{~A}$ & 6 \\
\hline
\end{tabular}

${ }^{1}$ Study ID were assigned to the 51 papers that were selected in the second-last selection step (Supplemental File S3, https://doi.org/10.3168/jds.2020-18193).

${ }^{2}$ Bovine viral diarrhea virus.

\section{Meta-Analyses}

Herd and Animal Characteristics. Herd type was studied frequently and was always included as a categorical variable (i.e., dairy, beef, mixed, beef breeding; Supplemental File S4, section 4.1.1, https:/ /doi.org/10.3168/jds.2020-18193). A meta-analysis was conducted on the 6 studies that compared dairy versus beef herds (reference category; Supplemental File S4, section 4.1.2). We found a combined effect estimate of

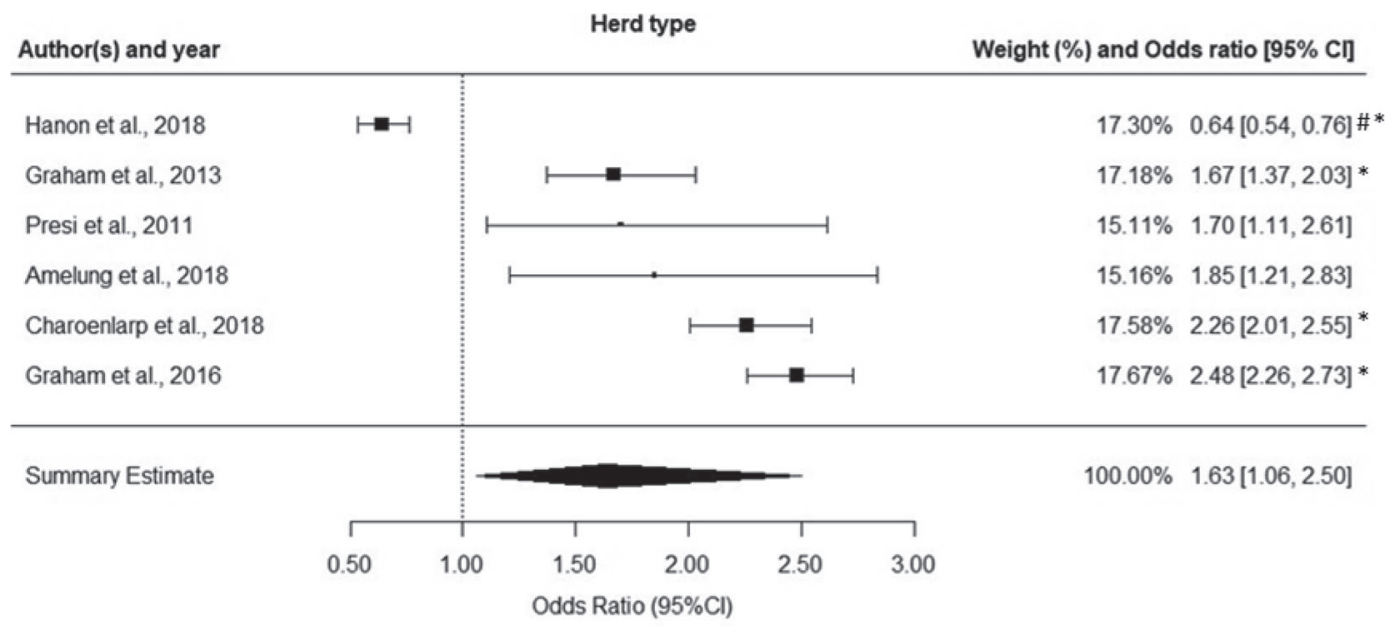

Herd size

\begin{tabular}{|c|c|c|c|c|c|c|c|c|}
\hline \multicolumn{7}{|l|}{ Author(s) and year } & \multicolumn{2}{|c|}{ Weight $(\%)$ and Odds ratio $[95 \% \mathrm{Cl}]$} \\
\hline Sarrazin et al., 2013 & & $H=$ & & & & & $40.989 \%$ & $1.004[1.002,1.006]^{\#}$ \\
\hline Amelung et al., 2018 & & 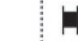 & & & & & $57.875 \%$ & $1.004[1.003,1.005]^{\#}$ \\
\hline Barrett et al., 2018 & & & & . & -1 & & $1.136 \%$ & $1.025[1.006,1.045]$ \\
\hline Summary Estimate & & & & & & & $100.000 \%$ & $1.004[1.002,1.006]$ \\
\hline & 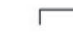 & i & $T$ & $T$ & $T$ & $\neg$ & & \\
\hline & 0.985 & 1.000 & 1.015 & 1.030 & 1.045 & 1.060 & & \\
\hline & & & Odds $\mathrm{R}$ & $(95 \% \mathrm{C}$ & & & & \\
\hline
\end{tabular}

Figure 2. Forest plot of the effect of herd type with beef herds as reference category (upper plot) and herd size per additional animal in the herd (lower plot) on bovine viral diarrhea virus infection. *Univariable result; \#study indicated as outlier in the influential case analysis. 
1.63 higher odds (95\% CI: 1.06-2.50) of BVDV infection in dairy herds compared with beef herds (Figure $2)$. The heterogeneity between studies $\left(\mathrm{I}^{2}\right)$ was $97.30 \%$ (95\% CI: 91.87-99.47).

Herd size was studied frequently and was always included as an either categorical or continuous variable (Supplemental File S4, section 4.1.1). However, very few variables were comparable; therefore, meta-analysis was conducted on the 4 studies with OR per additional cow (Supplemental File S4, section 4.1.2). Other variables showing the log number of cows or different herd size categories were not included because they were not comparable.

For every extra animal in the herd, we found a combined effect estimate of 1.004 higher odds (95\% CI:
1.002-1.006) of BVDV infection (Figure 2). For every 10 extra animals in the herd, this would be 1.04 higher odds of BVDV infection (95\% CI: 1.02-1.06). The results of Presi et al. (2011) could not be included in the pooled estimate because weights are assigned to all factors based on the inverse of the variance and these results had a variance of zero. The heterogeneity between studies $\left(\mathrm{I}^{2}\right)$ was $55.96 \%$ (95\% CI: 0.00-99.98).

Cattle Movement. In all studies, participation in cattle shows or markets was included as a yes-no variable (Supplemental File S4, section 4.2.1) and therefore they could all be included in meta-analysis (Supplemental File S4, section 4.2.2). We found a combined effect estimate of 1.45 higher odds (95\% CI: 1.10-1.91) of BVDV infection in herds that participated in shows

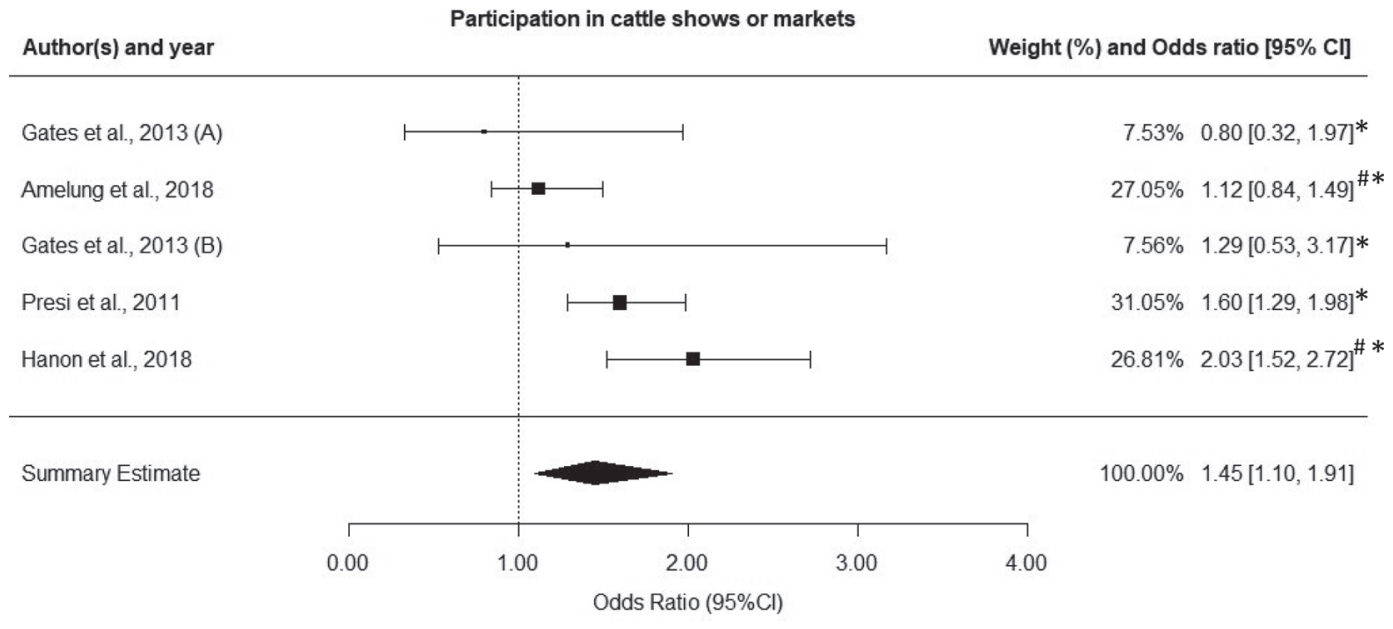

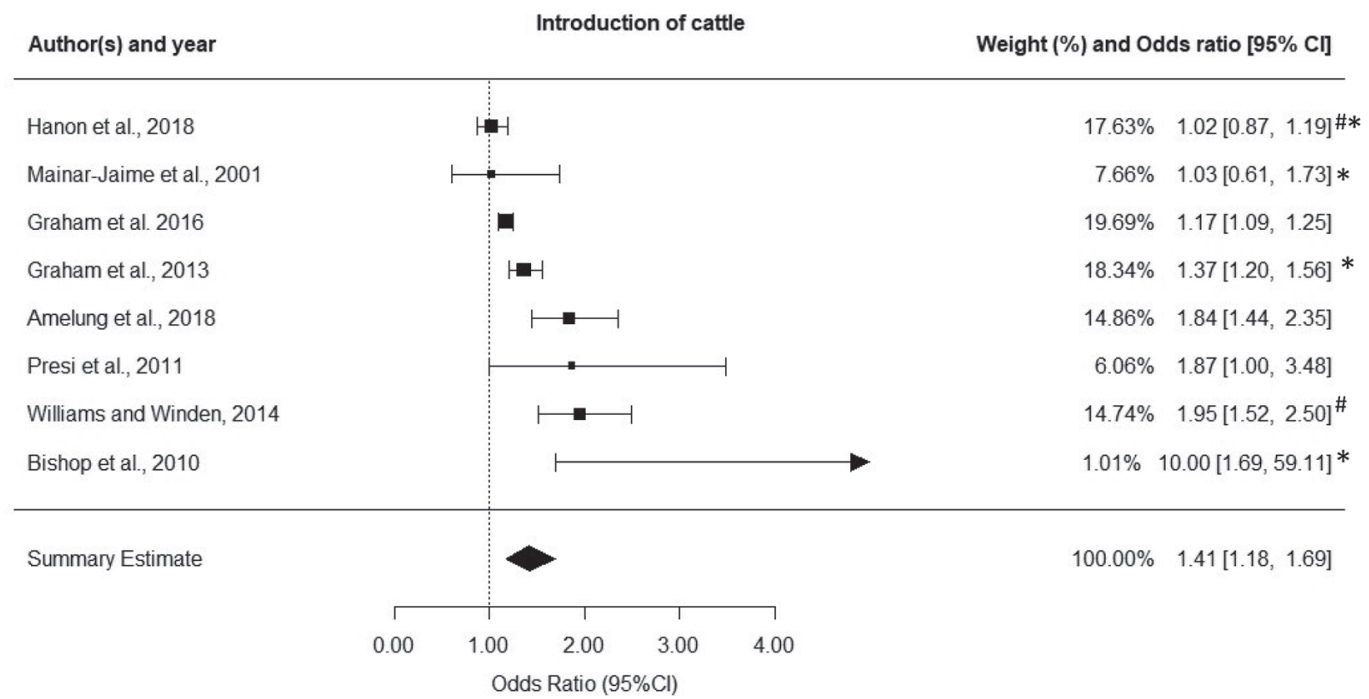

Figure 3. Forest plot of the effect of participation in shows or markets (upper plot) and introduction of cattle (lower plot) on bovine viral diarrhea virus infection. Gates et al., 2013 (A) and (B), refers to substudies, as indicated in Table 2. *Univariable result; \#study indicated as outlier in the influential case analysis. 
or markets compared with herds that did not (Figure $3)$. The heterogeneity between studies $\left(\mathrm{I}^{2}\right)$ was $61.70 \%$ (95\% CI: 0.00-96.60).

Introduction of cattle was the most often studied movement variable but was not easily compared between studies because of the many different ways in which introduction of cattle was coded (i.e., introduction yes-no, source of introduced animals, continuous variables, and introduction of different types of cattle). We decided to focus further meta-analysis on introduction yes-no because these variables were most comparable (Supplemental File S4, section 4.2.2). In 2 studies (Graham et al., 2013, 2016), a sub-meta-analysis was first performed to obtain pooled estimates comparable with the estimates of the yes-no variables (Supplemen- tal File S5, https://doi.org/10.3168/jds.2020-18193). We found a combined effect estimate of 1.41 higher odds (95\% CI: 1.18-1.69) of BVDV infection in herds that introduce cattle into the herd compared with herds that do not (Figure 3). The heterogeneity between studies $\left(\mathrm{I}^{2}\right)$ was $82.98 \%$ (95\% CI: 71.48-99.47).

Neighborhood Risk. Pasturing of cattle was the most often studied neighborhood risk variable. Variables described whether cattle had access to pasture, the possibility of contact with cattle from other herds at pasture, and shared pasture (Supplemental File S4, section 4.3.1). First studies were compared that looked at the presence versus absence of pasture (Supplemental File S4, section 4.3.2) followed by contact between cattle on pasture (Supplemental File S4, section 4.3.2).

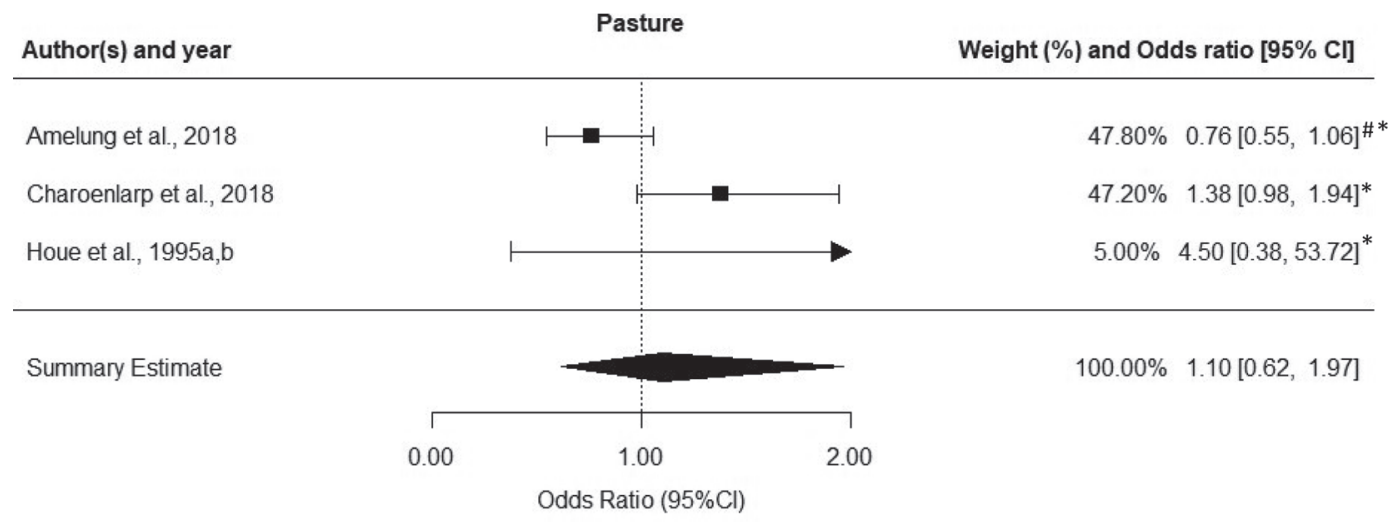

Contact between cattle at pasture

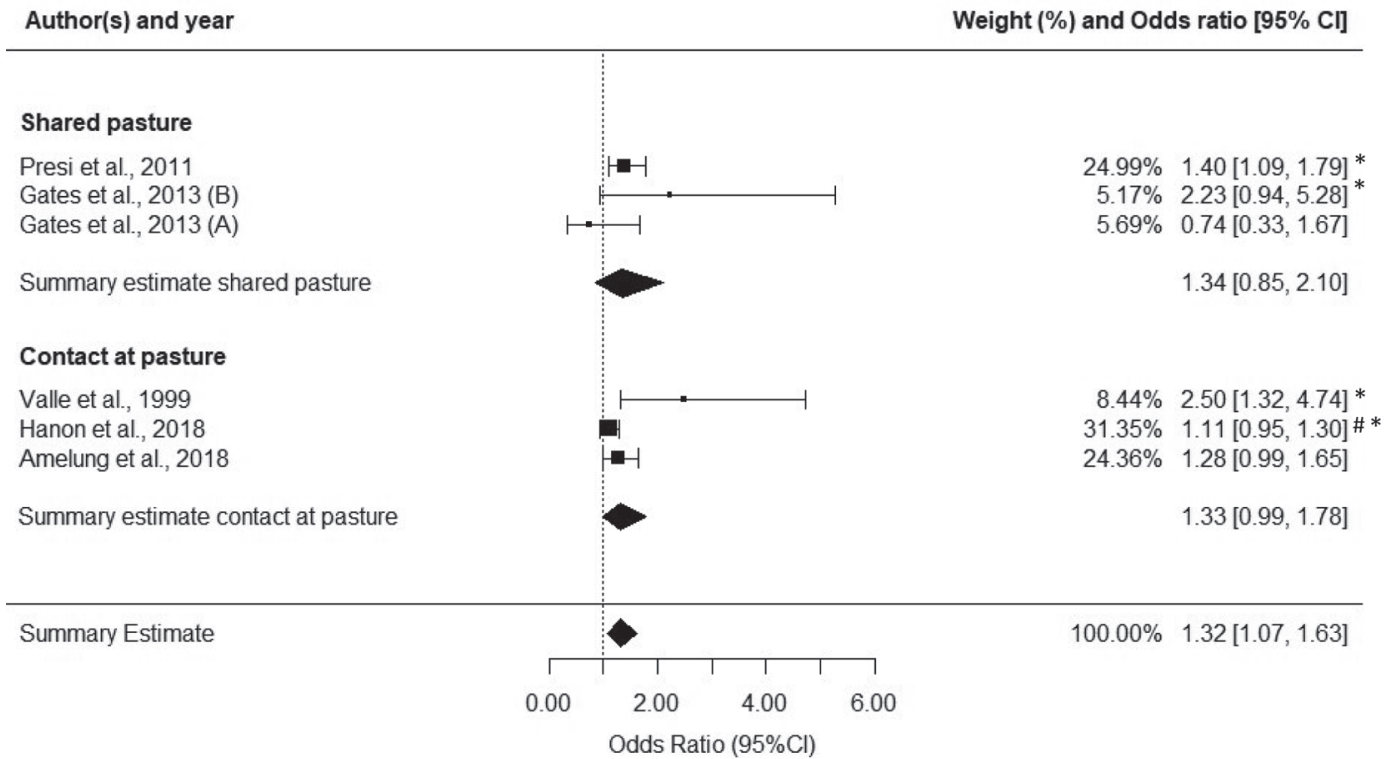

Figure 4. Forest plot of the effect of herds grazing (upper plot) and contact between cattle on pasture by either shared pasture or over-thefence contact (lower plot) on bovine viral diarrhea virus infection. Gates et al., 2013 (A) and (B), refers to substudies, as indicated in Table 2. *Univariable result; \#study indicated as outlier in the influential case analysis. 
We found a nonsignificant combined effect estimate of 1.10 higher odds (95\% CI: 0.62-1.97) of BVDV infection in herds that graze their cattle compared with herds that do not (Figure 4). The heterogeneity between studies $\left(\mathrm{I}^{2}\right)$ was $73.30 \%$ (95\% CI: 0.83-99.80). Studies on contact between cattle at pasture were divided into shared pasture and the possibility of contact with cattle from other herds at pasture (e.g., contact over the fence) but were also analyzed together (Figure 4).

For both shared pasture and contact at pasture, we found nonsignificant odds of BVDV infection: 1.34 (95\% CI: $0.85-2.10)$ and 1.33 (95\% CI: 0.99-1.78), respectively (Figure 4). However, we found an overall significant combined effect estimate of 1.32 higher odds (95\% CI: 1.07-1.63) of BVDV infection in herds where contact between cattle at pasture is possible either because different herds share pasture or because of contact between herds in contiguous pastures (Figure 4). The heterogeneity between studies $\left(\mathrm{I}^{2}\right)$ was $53.90 \%$ (95\% CI: 0.00-97.70).

\section{DISCUSSION}

By conducting this systematic literature search we have gained a comprehensive overview of potential risk factors for the presence of BVD in cattle herds. We decided to focus on studies performed in Europe in an attempt to reduce heterogeneity between results caused by different cattle production systems on different continents. However, the results could be generalized to areas outside Europe where there are similar cattle production systems (e.g., areas in the United States). The 18 European publications that were included in this study showed a wide range of potential risk factors that were grouped into 6 categories with similar characteristics: (1) herd and animal characteristics, (2) cattle movement, (3) reproduction, (4) neighborhood risk, (5) farm management and biosecurity, and (6) diagnostic testing and control programs. Although there was a lot of variation in risk factors between studies, we performed several meta-analyses and obtained pooled estimates for several frequently found risk factors.

Two herd characteristics that were frequently studied were herd size and herd type. Most studies found that larger herds were associated with higher odds of BVD infection. Only Hanon et al. (2018) found the highest seroprevalence in the smallest herds ( $<100$ cattle). They did find a higher seroprevalence in farms with a higher number of stables $(>3)$. The pooled estimate in our meta-analysis showed a significantly higher risk of infection per extra 10 animals in the herd $(\mathrm{OR}=1.04$, 95\% CI: 1.02-1.06). This could be explained by the tendency for larger herds to have a decreased probability of self-clearance of infection and to be more likely to contain a higher number of pregnant cattle and purchased cattle, increasing the risk of introduction of PI into the herd (Lindberg and Houe, 2005; Sarrazin et al., 2013; Barrett et al., 2018). In our meta-analysis, dairy herds were also found to be at higher risk of infection than beef herds (OR $=1.63,95 \%$ CI: $1.06-2.50)$. It has been suggested that this is related to the higher number of contacts between cattle and people and traffic on dairy farms compared with beef farms (Amelung et al., 2018).

Movement of cattle is considered one of the most important risk factors for BVD infection, especially purchase (Courcoul and Ezanno, 2010; Gates et al., 2013; Qi et al., 2019). Our meta-analysis showed higher odds $(\mathrm{OR}=1.41,95 \% \mathrm{CI}: 1.18-1.69)$ for herds that introduced cattle into the herd in the previous year compared with herds that did not. However, Gates et al. (2014) illustrated that not all purchased cattle pose the same risk. They found that purchase of pregnant heifers and open cows with a calf at foot are associated with a higher risk of BVDV infection in beef herds, with OR of 2.18 (95\% CI: $1.17-4.08$ ) and 2.09 (95\% CI: 1.13-3.88), respectively. The number of cattle introduced was also studied several times, generally showing increasing odds with increasing numbers of introduced cattle (Gates et al., 2013; Graham et al., 2013, 2016; Byrne at al., 2017). It was, however, suggested that the number of cattle introduced is related to herd size (Graham et al., 2016; Byrne et al., 2017), indicating the importance of correcting for herd size when studying purchase. A different way to study the risk of introduction is to look at the number of source herds. Gates et al. (2013) found a significant association between BVDV infection and a larger number of source herds in dairy herds ( $\mathrm{OR}=4.42$ in units of 10 farms, 95\% CI: $1.86-10.00)$ and beef herds (OR $=10.60$ in units of 10 farms, 95\% CI: 3.91-31.00). However, there was strong correlation between the number of cattle introduced and the number of source herds (Gates et al., 2013).

Another risk factor related to cattle movement that was studied frequently is participation in shows or markets. Our pooled estimate shows significant higher odds of infection for herds that visit cattle shows or markets $(\mathrm{OR}=1.45,95 \% \mathrm{CI}: 1.10-1.91)$ compared with herds that do not. This could be explained by the possibility that cattle come in contact with BVDV-infected cattle at the show or market and infect the herd upon returning or because of infection during transport.

No meta-analysis could be performed on any of the reproduction variables because of the low number of comparable studies. However, concerns have been raised about transmission of BVDV by AI (Gard et al., 
2007; Rikula et al., 2008). This may be prevented by regular testing of bulls at AI centers and testing of imported semen (Eaglesome and Garcia, 1997; Wentink et al., 2000; Lindberg et al., 2006). Also, the within-herd calving pattern could not be compared between studies, but Williams and Winden (2014) found an increased likelihood of BVDV presence with year-round calving compared with seasonal calving. They indicated that this could be related to the fact that with year-round calving there are almost always pregnant cows present within the susceptible window for BVDV infection of the fetus. When developing or optimizing BVD control programs, calving pattern could be an important factor to consider. In block calving systems, tissue tag testing of newborn calves provides the opportunity to identify and remove the majority of PI calves before the breeding season commences, reducing the risk of establishing more PI calves to be born the following season. In yearround calving systems, spot testing could be a costeffective option to monitor new infections (Tratalos et al., 2017).

Bovine viral diarrhea can easily spread between herds direct contact is possible between cattle (Tråvén et al., 1991). Therefore, grazing is considered a risk factor for BVD as nose-to-nose contact between cattle of different herds may occur. However, our pooled estimate did not show significant odds $(\mathrm{OR}=1.10$, 95\% CI: 0.62-1.97) for BVD infection for herds that graze compared with herds that do not. When results that indicated shared pasture were separated from results that indicated whether contact between cattle at pasture could occur (e.g., over-the-fence contact), our pooled estimates were nonsignificant, but when taken altogether and thus increasing statistical power, we found a significant effect indicating that contact between cattle at pasture had a higher odds of BVD infection $(\mathrm{OR}=1.32,95 \% \mathrm{CI}: 1.07-1.63)$. The risk of grazing is likely influenced by many factors, such as cattle density and the prevalence of BVDV in the area (Houe et al., 1995a), regulations around communal grazing (Rossmanith et al., 2005), the number of cattle and herds sharing pasture (Presi et al., 2011), and the number of neighbors.

In the current study, no meta-analysis was performed on any of the farm management and biosecurity variables due to the low number of studies and the differing ways in which biosecurity was measured. It was unexpected that most studies did not find a significant association between biosecurity measures and BVDV infection because biosecurity is considered an important aspect of BVDV control (Moennig et al., 2005; Lindberg et al., 2006). Gates et al. (2013) suggested that this could be related to the design of questionnaires (e.g., questionnaires that primarily use closed yes-no questions, which forces farmers to choose one of the options even if neither is completely true). Farmers could also give socially desirable answers because they fear possible consequences. Farmer behavior is another factor for which there were not enough quantitative data for meta-analysis. This lack of quantitative data does not necessarily mean that farmer behavior and biosecurity are not important factors for BVD, but they are more often studied qualitatively, which made it impossible to include them in the meta-analysis. Qualitative research into farmer behavior and biosecurity related to BVD stresses the importance of addressing farmer attitudes toward BVD control (Heffernan et al., 2016; Azbel-Jackson et al., 2018). A meta-analysis on epidemiological and mitigation measures that influence production losses in cattle due to BVDV has been reported (Pinior et al., 2019). These authors found that vaccination and biosecurity had a positive influence on the annual BVDV production losses per animal. We agree that farmers' attitudes toward BVD control and biosecurity-related measures are important and influence the effect of the risk factors we found in this paper. For example, when a new cow is kept in quarantine and tested for BVD before its introduction in the herd, the risk of introduction will be lower compared with new cows that are directly introduced in the herd. Therefore, we recommend further study of the quantitative association between BVD control and biosecurity and farmer behavior.

No meta-analysis could be performed on any of the diagnostic testing and control program variables because of both the small number of studies and the large variation between variables. One study found slightly higher odds for presence of BVDV when participating in control programs in univariable analysis (Amelung et al., 2018), which could probably be explained by the assumption that farms with BVDV problems are more likely to participate in a control program. Another interesting result was that herds of farmers younger than $40 \mathrm{yr}$ were more often infected than herds of older farmers (Valle et al., 1999). According to Valle et al. (1999), this is probably due to different attitudes and management practices of younger farmers, such as not asking for health certificates when purchasing animals. This would be an interesting factor to consider in future quantitative studies about BVDV infection and farmer behavior.

In our meta-analyses, several pooled estimates were significant. However, the results could be biased because most studies looked at the presence of BVDV and not introduction of the virus. With presence of infection, it is unknown when the actual infection happened, which complicates finding direct associations between infection and risk factors. However, this would prob- 
ably be less influential when considering risk factors that do not change much over time, such as whether herds graze at pasture, herd type, and herd size. When studying the introduction of BVDV, it is possible that there is a delay between introduction and detection. For example, a PI calf introduced on a farm that monitors by bulk milk testing is unlikely to be promptly detected unless individual animal testing is also conducted on newly imported animals on the farm. Such situations complicate efforts to identify direct associations between infection and risk factors. Therefore, we think that the presence of BVDV is a reasonable proxy for introduction of the virus. In addition, the presence of risk factors does not often change as they are part of regular farm management.

Another complicating factor in comparing different studies was the way in which herds were categorized as infected or not infected (e.g., based on antibodies or virus) using different sample types, tests, and strategies to confirm the infection status. These differences could be considered by performing a formal assessment of risk of bias. However, because we already had a low number of studies per meta-analysis, we did not want to exclude any more studies and decided to include only the most important internal and external validity checkpoints (Table 1). Also, not all information was available in each publication for a proper bias risk assessment.

For several risk factors, it was not appropriate to perform a meta-analysis given that there were not enough comparable studies with sufficient quantitative data. For the risk factors with sufficient data, the metaanalyses indicated high levels of heterogeneity. This was expected as all papers included in our meta-analyses were observational studies with different objectives, study designs, and context. For that reason, performing meta-analysis on observational studies and obtaining pooled estimates have been extensively debated (Egger et al., 1998; Blettner et al., 1999; Ioannidis et al., 2008). However, the number of published meta-analyses on observational data has substantially increased, and the need for guidelines for performing meta-analysis on observational data is emphasized (Mueller et al., 2018; Dekkers et al., 2019). In the current study, we decided to perform meta-analyses on observational studies to provide an overview of available quantitative data, including a weighted average estimate. In this subject area, quantitative risk factor information is available only from observational studies. A key principle underpinning this study is the potential for countries without local knowledge of risk factors for BVDV to learn from those countries where data are available. In our view, weighted average estimates have the potential to be more helpful to readers while being cognizant of het- erogeneity between studies rather than being solely a listing of all available quantitative results.

In our study, we tried to control for heterogeneity and bias as much as possible through the checklist of study appraisal for quantitative analysis (Table 1) and by very carefully choosing the factors that could be compared. The $\mathrm{I}^{2}$ statistics still showed a very high level of heterogeneity for all factors, but it is known to be not very accurate when only a small number of studies $(\mathrm{n}<20)$ are available (Huedo-Medina et al., 2006). Also, the very wide $95 \%$ CI of the $\mathrm{I}^{2}$ statistic we observed show the degree of uncertainty about the heterogeneity estimations. The influential case analyses showed that the $\mathrm{I}^{2}$ estimate was often lower when removing outliers from the meta-analyses; however, CI remained wide. Given this result, and because $\mathrm{I}^{2}$ is unreliable when few studies are available, we elected to retain the outliers but to show the summary estimates and $\mathrm{I}^{2}$ of each meta-analysis when excluding the outliers (Supplemental File S6, https://doi.org/10.3168/jds .2020-18193).

To maximize the amount of quantitative data, we decided to include both univariable and multivariable OR in our analyses. Therefore, in 3 of the 6 metaanalyses we combined univariable and multivariable results. The rationale behind this is that in different studies the multivariable OR were adjusted for different factors and referred to different reference situations and are therefore not necessarily more comparable than unadjusted univariable results. On the other hand, univariable OR can under- or overestimate the strength of association. As there is not yet a uniform approach regarding the use of univariable and multivariable results in meta-analysis, adjusted and unadjusted OR often are combined (Liu et al., 2017). As we decided to combine adjusted and unadjusted OR, we have performed subanalyses in which we compared the results when including only the univariable results or the multivariable results. In most cases we observed only minor differences. In the meta-analyses on herd type and introduction of cattle, we did see a substantial decrease in heterogeneity $\left(\mathrm{I}^{2}\right)$. However, keeping in mind that the $\mathrm{I}^{2}$ statistic becomes increasingly unreliable when even fewer studies are included and because the summary estimates did not change that much, we decided to combine univariable and multivariable results. The results of the subnalyses are reported in Supplemental File S7 (https://doi.org/10.3168/jds.2020-18193). We also selected different observational study designs to maximize the number of studies in our meta-analyses. Therefore, in 2 of the 6 meta-analyses (participation in cattle shows and markets and contact between cattle at pasture) we combined cross-sectional studies with 
case-control studies. In the scientific literature, there is disagreement about whether different study designs can be combined (Mueller et al., 2018). The influential case analysis was conducted to determine whether the case-control studies (only 3 out of 20 studies) were indicated as outliers, which they were not. Consequently, leaving them out would not make much difference, and therefore we decided to retain both study designs. We note that these 2 study designs are differing types of observational studies and use OR as outcome.

All studies included in our meta-analyses used OR to show the strength of association between risk factors and BVD infection. It should be kept in mind that these OR are based on a certain reference population and are therefore sensitive to how the reference category is defined. For this reason, it can be questioned whether $\mathrm{OR}$ are the right means to compare studies. It would have been better to obtain probabilities of infection and risk factor occurrence. However, given that these were often not reported and the fact that OR do provide a rough risk estimate, it was decided to conduct the meta-analysis on OR. This should be considered when interpreting the results of this study.

\section{CONCLUSIONS}

In this study, we found a wide range of potential risk factors and performed meta-analyses on 6 risk factors for BVDV: herd size, herd type, participation in shows or markets, introduction of cattle, pasture, and contact at pasture. We did not find any unexpected risk factors, and the pooled estimates can help guide advice to farmers and assist in the development, evaluation, and optimization of BVD control programs. The results of the meta-analyses must be interpreted with care due to a high level of study heterogeneity but can assist in the development, evaluation, and optimization of BVD control programs. They can also be used as input for BVDV modeling studies in herds that are comparable with the European cattle production systems. It was challenging to combine estimates of different studies due to heterogeneity between studies (e.g., study design, data analysis, data reporting), showing the need for more standardized methodologies in risk factor studies.

\section{ACKNOWLEDGMENTS}

This work was carried out with the financial support of the Dutch Ministry of Agriculture, Nature and Food Quality (the Hague, the Netherlands) and is part of the STOC free project that was awarded a grant by the European Food Safety Authority (EFSA, Parma, Italy) and was co-financed by public organizations in the countries participating in the study. The authors have not stated any conflicts of interest.

\section{REFERENCES}

AHI (Animal Health Ireland). 2019. Programme results. Accessed Sep. 17, 2019. http://animalhealthireland.ie/?page_id $=229$.

Almeida, L. L., I. C. S. Miranda, H. E. Hein, W. S. Neto, E. F. Costa, F. S. Marks, C. R. Rodenbusch, C. W. Canal, and L. G. Corbellini. 2013. Herd-level risk factors for bovine viral diarrhea virus infection in dairy herds from Southern Brazil. Res. Vet. Sci. 95:901-907. https://doi.org/10.1016/j.rvsc.2013.08.009.

Amelung, S., M. Hartmann, L. Haas, and L. Kreienbrock. 2018. Factors associated with the bovine viral diarrhoea (BVD) status in cattle herds in Northwest Germany. Vet. Microbiol. 216:212-217. https://doi.org/10.1016/j.vetmic.2018.01.018.

Aragaw, K., B. Sibhat, G. Ayelet, E. Skjerve, E. Z. Gebremedhin, and K. Asmare. 2018. Seroprevalence and factors associated with bovine viral diarrhea virus (BVDV) infection in dairy cattle in three milksheds in Ethiopia. Trop. Anim. Health Prod. 50:1821-1827. https://doi.org/10.1007/s11250-018-1624-5.

Aye, Y. M., M. Aung, W. O. Kyaw, T. Naing, and S. P. Po. 2017. Prevalence and associated factors with bovine viral diarrhoea virus antibodies in the bulk tank milk of small scale dairy herds in central Myanmar. Adv. Anim. Vet. Sci. 5:316-323. https://doi.org/10 .17582 /journal.aavs/2017/5.8.316.323.

Azbel-Jackson, L., C. Heffernan, G. Gunn, and J. Brownlie. 2018. Exploring the role of voluntary disease schemes on UK farmer bio-security behaviours: Findings from the Norfolk-Suffolk Bovine Viral Diarrhoea control scheme. PLoS One 13:e0179877. https:// doi.org/10.1371/journal.pone.0179877.

Barrett, D., M. Parr, J. Fagan, A. Johnson, J. Tratalos, F. Lively, M. Diskin, and D. Kenny. 2018. Prevalence of bovine viral diarrhoea virus (BVDV), bovine herpes virus 1 (BHV 1), leptospirosis and neosporosis, and associated risk factors in 161 Irish beef herds. BMC Vet. Res. 14:8. https://doi.org/10.1186/s12917-017-1324-9.

Bedeković, T., N. Lemo, L. Barbić, Ž. Cvetnić, I. Lojkić, M. Benić, Ž. Čač, M. Lojkić, and J. Madić. 2013. Influence of category, herd size, grazing and management on epidemiology of bovine viral diarrhoea in dairy herds. Acta Vet. Brno 82:125-130. https://doi .org/10.2754/avb201382020125.

Bishop, H., J. Erkelens, and S. Van Winden. 2010. Indications of a relationship between buying-in policy and infectious diseases on dairy farms in Wales. Vet. Rec. 167:644-647. https://doi.org/10 $.1136 /$ vr.c5256.

Bitsch, V., K. E. Hansen, and L. Rønsholt. 2000. Experiences from the Danish programme for eradication of bovine virus diarrhoea (BVD) 1994-1998 with special reference to legislation and causes of infection. Vet. Microbiol. 77:137-143. https://doi.org/10.1016/ s0378-1135(00)00270-4.

Blettner, M., W. Sauerbrei, B. Schlehofer, T. Scheuchenpflug, and C. Friedenreich. 1999. Traditional reviews, meta-analyses and pooled analyses in epidemiology. Int. J. Epidemiol. 28:1-9. https://doi .org/10.1093/ije/28.1.1.

Borenstein, M., J. P. Higgins, L. V. Hedges, and H. R. Rothstein. 2017. Basics of meta-analysis: I2 is not an absolute measure of heterogeneity. Res. Synth. Methods 8:5-18. https://doi.org/10.1002/ jrsm.1230.

Buitrago Horta, E. R., C. Jiménez Escobar, and J. L. Zambrano Varón. 2018. Identification of factors associated with exposure to bovine viral diarrhea virus (BVDV) in dairy-herd calves in the Bogotá savanna. Rev. Med. Vet. 36:63-73. https://doi.org/10.19052/ mv. 5172 .

Byrne, A. W., M. Guelbenzu-Gonzalo, S. A. J. Strain, S. McBride, J. Graham, A. Lahuerta-Marin, R. Harwood, D. A. Graham, and S. McDowell. 2017. Assessment of concurrent infection with bovine viral diarrhoea virus (BVDV) and Mycobacterium bovis: A herdlevel risk factor analysis from Northern Ireland. Prev. Vet. Med. 141:38-47. https://doi.org/10.1016/j.prevetmed.2017.04.007. 
Carbonero, A., A. Maldonado, A. Perea, I. García-Bocanegra, C. Borge, A. Torralbo, A. Arenas-Montes, and A. Arenas-Casas. 2011. Risk factors against bovine respiratory disease in suckling calves from Argentina. Arch. Zootec. 60:41-51. https://doi.org/10 .21071/az.v60i229.4687.

Charoenlarp, W., K. Frankena, S. A. J. Strain, M. Guelbenzu-Gonzalo, J. Graham, and A. W. Byrne. 2018. Spatial and risk factor analysis of bovine viral diarrhoea (BVD) virus after the first-year compulsory phase of BVD eradication programme in Northern Ireland. Prev. Vet. Med. 157:34-43. https://doi.org/10.1016/j .prevetmed.2018.05.011.

Chi, J., J. A. Van Leeuwen, A. Weersink, and G. P. Keefe. 2002. Management factors related to seroprevalences to bovine viraldiarrhoea virus, bovine-leukosis virus, Mycobacterium avium subspecies paratuberculosis, and Neospora caninum in dairy herds in the Canadian Maritimes. Prev. Vet. Med. 55:57-68. https://doi .org/10.1016/s0167-5877(02)00067-3.

Courcoul, A., and P. Ezanno. 2010. Modelling the spread of bovine viral diarrhoea virus (BVDV) in a managed metapopulation of cattle herds. Vet. Microbiol. 142:119-128. https://doi.org/10.1016/j .vetmic.2009.09.052.

Cuttance, W. G., and E. L. Cuttance. 2014. Analysis of individual farm investigations into bovine viral diarrhoea in beef herds in the North Island of New Zealand. N. Z. Vet. J. 62:338-342. https://doi .org/10.1080/00480169.2014.928925.

Dekkers, O. M., J. P. Vandenbroucke, M. Cevallos, A. G. Renehan, D. G. Altman, and M. Egger. 2019. COSMOS-E: Guidance on conducting systematic reviews and meta-analyses of observational studies of etiology. PLoS Med. 16:e1002742. https://doi.org/10 .1371/journal.pmed.1002742.

Downes, M. J., M. L. Brennan, H. C. Williams, and R. S. Dean. 2016. Development of a critical appraisal tool to assess the quality of cross-sectional studies (AXIS). BMJ Open 6:e011458. https://doi .org/10.1136/bmjopen-2016-011458.

Eaglesome, M. D., and M. M. Garcia. 1997. Disease risks to animal health from artificial insemination with bovine semen. Rev. Sci. Tech. Off. Int. Epiz. 16:215-225. https://doi.org/10.20506/rst.16 .1 .1017 .

Egger, M., M. Schneider, and G. D. Smith. 1998. Spurious precision? Meta-analysis of observational studies. BMJ 316:140-144. https:// doi.org/10.1136/bmj.316.7125.140.

Erfani, A. M., M. Bakhshesh, M. H. Fallah, and M. Hashemi. 2019. Seroprevalence and risk factors associated with bovine viral diarrhea virus and bovine herpes virus-1 in Zanjan Province, Iran. Trop. Anim. Health Prod. 51:313-319. https://doi.org/10.1007/ s11250-018-1687-3.

Ersbøll, A. K., B. K. Ersbøll, H. Houe, L. Alban, and A. M. Kjeldsen. 2010. Spatial modelling of the between-herd infection dynamics of bovine virus diarrhoea virus (BVDV) in dairy herds in Denmark. Prev. Vet. Med. 97:83-89. https://doi.org/10.1016/j.prevetmed .2010.08.004

Fernandes, L. G., A. H. de Campos Nogueira, E. De Stefano, E. M. Pituco, C. P. Ribeiro, C. J. Alves, T. S. Oliveira, I. J. Clementino, and S. S. de Azevedo. 2016. Herd-level prevalence and risk factors for bovine viral diarrhea virus infection in cattle in the State of Paraíba, Northeastern Brazil. Trop. Anim. Health Prod. 48:157165. https://doi.org/10.1007/s11250-015-0937-x.

Foddai, A., A. Stockmarr, and A. Boklund. 2016. Evaluation of temporal surveillance system sensitivity and freedom from bovine viral diarrhea in Danish dairy herds using scenario tree modelling. BMC Vet. Res. 12:118. https://doi.org/10.1186/s12917-016-0744-2.

Gädicke, P., T. Junod, J. López-Martin, R. Ortega, and G. Monti. 2016. Enfermedades abortigénicas en lecherías de la Provincia de Nuble: Prevalencia y análisis espacial. Arch. Med. Vet. 48:18-26. https://doi.org/10.4067/S0301-732X2016000100003.

Gard, J. A., M. D. Givens, and D. A. Stringfellow. 2007. Bovine viral diarrhea virus (BVDV): Epidemiologic concerns relative to semen and embryos. Theriogenology 68:434-442. https://doi.org/10 .1016/j.theriogenology.2007.04.003.

Gates, M. C., R. W. Humphry, G. J. Gunn, and M. E. Woolhouse. 2014. Not all cows are epidemiologically equal: Quantifying the risks of bovine viral diarrhoea virus (BVDV) transmission through cattle movements. Vet. Res. 45:110. https://doi.org/10.1186/ s13567-014-0110-y.

Gates, M. C., M. E. J. Woolhouse, G. J. Gunn, and R. W. Humphry 2013. Relative associations of cattle movements, local spread, and biosecurity with bovine viral diarrhoea virus (BVDV) seropositivity in beef and dairy herds. Prev. Vet. Med. 112:285-295. https:// doi.org/10.1016/j.prevetmed.2013.07.017.

Graham, D. A., T. A. Clegg, M. Lynch, and S. J. More. 2013. Herdlevel factors associated with the presence of bovine viral diarrhoea virus in herds participating in the voluntary phase of the Irish national eradication programme. Prev. Vet. Med. 112:99-108. https: //doi.org/10.1016/j.prevetmed.2013.07.011.

Graham, D. A., T. A. Clegg, H. H. Thulke, P. O'sullivan, G. McGrath, and S. J. More. 2016. Quantifying the risk of spread of bovine viral diarrhoea virus (BVDV) between contiguous herds in Ireland. Prev. Vet. Med. 126:30-38. https://doi.org/10.1016/j.prevetmed .2016.01.017.

Hanon, J. B., M. De Baere, C. de la Ferté, S. Roelandt, G. Guillot, Y. Van der Stede, and B. Cay. 2018. Serological monitoring on milk and serum samples in a BVD eradication program: A field study in Belgium showing antibody ELISA performances and epidemiological aspects. Prev. Vet. Med. 160:136-144. https://doi.org/10.1016/ j.prevetmed.2018.07.008.

Harrer, M., P. Cuijpers, T. A. Furukawa, and D. D. Ebert. 2019. Doing Meta-Analysis in R: A Hands-on Guide. Accessed Nov. 20, 2019. https://bookdown.org/MathiasHarrer/Doing_Meta_Analysis_in - R/.

Heffernan, C., L. Azbel-Jackson, J. Brownlie, and G. Gunn. 2016. Farmer attitudes and livestock disease: Exploring citizenship behaviour and peer monitoring across two BVD control schemes in the UK. PLoS One 11:e0152295. https://doi.org/10.1371/journal .pone.0152295.

Herrera-Yunga, V., J. Labada, F. Castillo, A. Torres, G. EscuderoSanchez, M. Capa-Morocho, and R. Abad-Guaman. 2018. Prevalence of antibodies and risk factors to bovine viral diarrhea in nonvaccinated dairy cattle from southern Ecuador. Trop. Subtrop. Agroecosystems 21:11-18.

Higgins, J. P. T., J. Thomas, J. Chandler, M. Cumpston, T. Li, M. J. Page, and V. A. Welch. 2019. Cochrane Handbook for Systematic Reviews of Interventions. Version 6.0. Accessed July 7, 2019. www .training.cochrane.org/handbook.

Houe, H. 2003. Economic impact of BVDV infection in dairies. Biologicals 31:137-143. https://doi.org/10.1016/s1045-1056(03)00030-7.

Houe, H. J. C. Baker, R. K. Maes, J. W. Lloyd, and C. Enevoldsen. 1995a. Comparison of the prevalence and incidence of infection with bovine virus diarrhoea virus (BVDV) in Denmark and Michigan and association with possible risk factors. Acta Vet. Scand. $36: 521-531$

Houe, H., J. C. Baker, R. K. Maes, P. L. Ruegg, and J. W. Lloyd. 1995b. Application of antibody titers against bovine viral diarrhea virus (BVDV) as a measure to detect herds with cattle persistently infected with BVDV. J. Vet. Diagn. Invest. 7:327-332. https://doi .org/10.1177/104063879500700305.

Huedo-Medina, T. B., J. Sánchez-Meca, F. Marín-Martínez, and J. Botella. 2006. Assessing heterogeneity in meta-analysis: Q statistic or I ${ }^{2}$ index? Psychol. Methods 11:193-206. https://doi.org/10 .1037/1082-989X.11.2.193.

Hult, L., and A. Lindberg. 2005. Experiences from BVDV control in Sweden. Prev. Vet. Med. 72:143-148. https://doi.org/10.1016/j .prevetmed.2005.04.005.

Humphry, R. W., F. Brülisauer, I. J. McKendrick, P. F. Nettleton, and G. J. Gunn. 2012. Prevalence of antibodies to bovine viral diarrhoea virus in bulk tank milk and associated risk factors in Scottish dairy herds. Vet. Rec. 171:445. https://doi.org/10.1136/ vr.100542.

Ioannidis, J. P., N. A. Patsopoulos, and H. R. Rothstein. 2008. Reasons or excuses for avoiding meta-analysis in forest plots. BMJ 336:1413-1415. https://doi.org/10.1136/bmj.a117.

Kadohira, M., and M. Tajima. 2010. A case control study of bovine viral diarrhea virus (BVDV) persistent infection (PI) in Betsukai, 
Hokkaido, Japan. J. Vet. Med. Sci. 72:635-638. https://doi.org/10 $.1292 /$ jvms.09-0305.

Kumar, S. K., K. M. Palanivel, K. Sukumar, B. S. M. Ronald, G. Selvaraju, and G. Ponnudurai. 2018. Herd-level risk factors for bovine viral diarrhea infection in cattle of Tamil Nadu. Trop. Anim. Health Prod. 50:793-799. https://doi.org/10.1007/s11250 $-017-1497-z$

Lindberg, A., J. Brownlie, G. Gunn, H. Houe, V. Moening, H. W. Saatkamp, T. Sandvik, and P. S. Valle. 2006. The control of bovine viral diarrhoea virus in Europe: Today and in the future. Rev. Sci. Tech. Off. Int. Epiz. 25:961-979.

Lindberg, A., and H. Houe. 2005. Characteristics in the epidemiology of bovine viral diarrhea virus (BVDV) of relevance to control. Prev. Vet. Med. 72:55-73. https://doi.org/10.1016/j.prevetmed 2005.07.018

Liu, T., X. Nie, Z. Wu, Y. Zhang, G. Feng, S. Cai, Y. Lv, and X. Peng. 2017. Can statistic adjustment of OR minimize the potential confounding bias for meta-analysis of case-control study? A secondary data analysis. BMC Med. Res. Methodol. 17:179. https://doi.org/ 10.1186/s12874-017-0454-x.

Luzzago, C., M. Frigerio, R. Piccinini, V. Daprà, and A. Zecconi. 2008. A scoring system for risk assessment of the introduction and spread of bovine viral diarrhoea virus in dairy herds in Northern Italy. Vet. J. 177:236-241. https://doi.org/10.1016/j.tvjl.2007.04 .017 .

Machado, G., R. M. F. Egocheaga, H. E. Hein, I. C. S. Miranda, W. S. Neto, L. L. Almeida, C. W. Canal, M. C. Stein, and L. G. Corbellini. 2016. Bovine Viral Diarrhoea Virus (BVDV) in dairy cattle: A matched case-control study. Transbound. Emerg. Dis. 63:e1-e13. https://doi.org/10.1111/tbed.12219.

Mainar-Jaime, R. C., B. Berzal-Herranz, P. Arias, and F. A. RojoVázquez. 2001. Epidemiological pattern and risk factors associated with bovine viral-diarrhoea virus (BVDV) infection in a non-vaccinated dairy-cattle population from the Asturias region of Spain. Prev. Vet. Med. 52:63-73. https://doi.org/10.1016/s0167 $-5877(01) 00239-2$

Martinez-Ibeas, A. M., C. Power, J. McClure, and R. G. Sayers. 2015. Prevalence of BoHV-1 seropositive and BVD virus positive bulls on Irish dairy farms and associations between bull purchase and herd status. Ir. Vet. J. 68:28. https://doi.org/10.1186/s13620-015 $-0059-9$.

McClurkin, A. W., E. T. Littledike, R. C. Cutlip, G. H. Frank, M. F. Coria, and S. R. Bolin. 1984. Production of cattle immunotolerant to bovine viral diarrhea virus. Can. J. Comp. Med. 48:156.

Milián-Suazo, F., R. Hernández-Ortíz, L. Hernández-Andrade, A. Alvarado-Islas, E. Díaz-Aparicio, F. Mejía-Estrada, E. G. PalomaresReséndiz, I. Bárcenas Reyes, and H. Zendejas-Martínez. 2016. Seroprevalence and risk factors for reproductive diseases in dairy cattle in Mexico. J. Vet. Med. Anim. Health 8:89-98. https://doi .org/10.5897/JVMAH2016.0483.

Mockeliūniene, V., A. Šalomskas, R. Mockeliūnas, and S. Petkevičius. 2004. Prevalence and epidemiological features of bovine viral diarrhoea virus infection in Lithuania. Vet. Microbiol. 99:51-57. https: //doi.org/10.1016/j.vetmic.2003.11.008.

Moennig, V., H. Houe, and A. Lindberg. 2005. BVD control in Europe: Current status and perspectives. Anim. Health Res. Rev. 6:63-74. https://doi.org/10.1079/ahr2005102.

Moher, D., A. Liberati, J. Tetzlaff, and D. G. Altman. 2009. Preferred Reporting Items for Systematic Reviews and Meta-Analyses: The PRISMA statement. PLoS Med. 6:e1000097. https://doi.org/10 .1371/journal.pmed.1000097.

Mueller, M., M. D'Addario, M. Egger, M. Cevallos, O. Dekkers, C. Mugglin, and P. Scott. 2018. Methods to systematically review and meta-analyse observational studies: A systematic scoping review of recommendations. BMC Med. Res. Methodol. 18:44. https://doi .org/10.1186/s12874-018-0495-9.

National Institutes of Health. 2014. Study quality assessment tools. Accessed Sep. 17, 2019. https://www.nhlbi.nih.gov/health-topics/ study-quality-assessment-tools.
Nava, L., P. Bracamonte, D. Hidalgo, and L. D. G. Escobar. 2013. Seroprevalence of bovine viral diarrhea in milk producing herds at Barinas State, Venezuela. Rev. Soc. Venez. Microbiol. 33:162-168.

Niskanen, R., and A. Lindberg. 2003. Transmission of bovine viral diarrhoea virus by unhygienic vaccination procedures, ambient air and from contaminated pens. Vet. J. 165:125-130. https://doi.org/ 10.1016/s1090-0233(02)00161-2.

Norström, M., M. E. Jonsson, J. Åkerstedt, A. C. Whist, A. B. Kristoffersen, S. Sviland, P. Hopp, and H. Wahlström. 2014. Estimation of the probability of freedom from bovine virus diarrhoea virus in Norway using scenario tree modelling. Prev. Vet. Med. 116:37-46. https://doi.org/10.1016/j.prevetmed.2014.06.012.

Nuotio, L., M. Juvonen, E. Neuvonen, L. Sihvonen, and J. Husu-Kallio. 1999. Prevalence and geographic distribution of bovine viral diarrhoea (BVD) infection in Finland 1993-1997. Vet. Microbiol. 64:231-235. https://doi.org/10.1016/s0378-1135(98)00272-7.

Olafson, P., and C. G. Rickard. 1947. Further observations on the virus diarrhea (new transmissible disease) of cattle. Cornell Vet. 37:104-106.

Pinior, B., S. Garcia, J. J. Minviel, and D. Raboisson. 2019. Epidemiological factors and mitigation measures influencing production losses in cattle due to bovine viral diarrhoea virus infection: A meta-analysis. Transbound. Emerg. Dis. 66:2426-2439. https:// doi.org/10.1111/tbed.13300.

Presi, P., R. Struchen, T. Knight-Jones, S. Scholl, and D. Heim. 2011. Bovine viral diarrhea (BVD) eradication in Switzerland-Experiences of the first two years. Prev. Vet. Med. 99:112-121. https:// doi.org/10.1016/j.prevetmed.2011.01.012.

Qi, L., G. Beaunée, S. Arnoux, B. L. Dutta, A. Joly, E. Vergu, and P. Ezanno. 2019. Neighbourhood contacts and trade movements drive the regional spread of bovine viral diarrhoea virus (BVDV). Vet. Res. 50:30. https://doi.org/10.1186/s13567-019-0647-x.

Quevedo, D. C., B. B. Benavides, G. Cárdenas, and C. Herrera. 2011 Seroprevalence and risk factors associated to BHV-1 and DVBV in dairy herds in Pasto, Colombia, in 2011. Rev. Lasallista Investig. 8:61-68.

R Core Team. 2019. R: A Language and Environment for Statistical Computing. R Foundation for Statistical Computing, Vienna, Austria.

Ramírez Vásquez, N. F., D. Villar Argaiz, J. A. Fernández Silva, J. Londoño Pino, J. J. Chaparro Gutiérrez, and M. E. Olivera Ángel. 2016. Seroprevalence and risk factors of several bovine viral diseases in dairy farms of San Pedro de los Milagros, Antioquia, Colombia. CES Med. Vet. Zootec. 11:15-25. https://doi.org/10 .21615/cesmvz.11.1.2.

Rêgo, M. J. P., A. F. B. Batista Filho, P. R. F. de Oliveira, J. de Melo Borges, C. A. B. de França, C. P. Ribeiro, E. M. Pituco, and J. W. Pinheiro Junior. 2016. Epidemiological analysis of infection by the bovine viral diarrhea virus on family farms in Brazil. Semin Cienc. Agrar. 37:4119-4129. https://doi.org/10.5433/1679-0359 .2016v37n6p4119.

Rikula, U., L. Nuotio, T. Aaltonen, and O. Ruoho. 2005. Bovine viral diarrhoea virus control in Finland 1998-2004. Prev. Vet. Med. 72:139-142. https://doi.org/10.1016/j.prevetmed.2005.08.010.

Rikula, U., L. Nuotio, U. I. Laamanen, and L. Sihvonen. 2008. Transmission of bovine viral diarrhoea virus through the semen of acutely infected bulls under field conditions. Vet. Rec. 162:79-82. https: //doi.org/10.1136/vr.162.3.79.

Rossmanith, W., M. Deinhofer, R. Janacek, R. Trampler, and E. Wilhelm. 2010. Voluntary and compulsory eradication of bovine viral diarrhoea virus in Lower Austria. Vet. Microbiol. 142:143-149. https://doi.org/10.1016/j.vetmic.2009.09.055.

Rossmanith, W., R. Janacek, and E. Wilhelm. 2005. Control of BVDVinfection on common grassland-The key for successful BVDVeradication in Lower Austria. Prev. Vet. Med. 72:133-137. https:/ /doi.org/10.1016/j.prevetmed.2005.05.012.

Saa, L. R., A. Perea, I. García-Bocanegra, A. J. Arenas, D. V. Jara, R. Ramos, and A. Carbonero. 2012. Seroprevalence and risk factors associated with bovine viral diarrhea virus (BVDV) infection in non-vaccinated dairy and dual purpose cattle herds in Ecuador. 
Trop. Anim. Health Prod. 44:645-649. https://doi.org/10.1007/ s11250-011-9948-4.

Sanderson, S., I. D. Tatt, and J. Higgins. 2007. Tools for assessing quality and susceptibility to bias in observational studies in epidemiology: A systematic review and annotated bibliography. Int. J. Epidemiol. 36:666-676. https://doi.org/10.1093/ije/dym018.

Sarrazin, S., A. Veldhuis, E. Méroc, I. Vangeel, J. Laureyns, J. Dewulf, A. B. Caij, S. Piepers, J. Hooyberghs, S. Ribbens, and Y. Van Der Stede. 2013. Serological and virological BVDV prevalence and risk factor analysis for herds to be BVDV seropositive in Belgian cattle herds. Prev. Vet. Med. 108:28-37. https://doi.org/10.1016/ j.prevetmed.2012.07.005.

Scharnböck, B., F.-F. Roch, V. Richter, C. Funke, C. L. Firth, W. Obritzhauser, W. Baumgartner, A. Käsbohrer, and B. Pinior. 2018. A meta-analysis of bovine viral diarrhoea virus (BVDV) prevalences in the global cattle population. Sci. Rep. 8:14420. https://doi.org/ 10.1038/s41598-018-32831-2.

Scott, H. M., O. Sorensen, J. T. Wu, E. Y. Chow, K. Manninen, and J. A. VanLeeuwen. 2006. Seroprevalence of Mycobacterium avium subspecies paratuberculosis, Neospora caninum, Bovine leukemia virus, and Bovine viral diarrhea virus infection among dairy cattle and herds in Alberta and agroecological risk factors associated with seropositivity. Can. Vet. J. 47:981.

Segura-Correa, J. C., J. L. Solorio-Rivera, and L. G. Sánchez-Gil. 2010. Seroconversion to bovine viral diarrhoea virus and infectious bovine rhinotracheitis virus in dairy herds of Michoacan, Mexico. Trop. Anim. Health Prod. 42:233-238. https://doi.org/10.1007/ s11250-009-9411-y.

Segura-Correa, J. C., C. C. Zapata-Campos, J. O. Jasso-Obregón, J. Martinez-Burnes, and R. López-Zavala. 2016. Seroprevalence and risk factors associated with bovine herpesvirus 1 and bovine viral diarrhea virus in North-Eastern Mexico. Open Vet. J. 6:143-149. https://doi.org/10.4314/ovj.v6i2.12.

Selim, A. M., M. M. Elhaig, S. A. Moawed, and E. El-Nahas. 2018. Modeling the potential risk factors of bovine viral diarrhea prevalence in Egypt using univariable and multivariable logistic regression analyses. Vet. World 11:259-267. https://doi.org/10.14202/ vetworld.2018.259-267.

Solis-Calderon, J. J., V. M. Segura-Correa, and J. C. Segura-Correa. 2005. Bovine viral diarrhoea virus in beef cattle herds of Yucatan, Mexico: Seroprevalence and risk factors. Prev. Vet. Med. 72:253262. https://doi.org/10.1016/j.prevetmed.2005.06.004

Sun, W. W., Q. F. Meng, W. Cong, X. F. Shan, C. F. Wang, and A. D. Qian. 2015. Herd-level prevalence and associated risk fac- tors for Toxoplasma gondii, Neospora caninum, Chlamydia abortus and bovine viral diarrhoea virus in commercial dairy and beef cattle in eastern, northern and northeastern China. Parasitol. Res. 114:4211-4218. https://doi.org/10.1007/s00436-015-4655-0.

Talafha, A. Q., S. M. Hirche, M. M. Ababneh, A. M. Al-Majali, and M. M. Ababneh. 2009. Prevalence and risk factors associated with bovine viral diarrhea virus infection in dairy herds in Jordan. Trop. Anim. Health Prod. 41:499-506. https://doi.org/10.1007/ s11250-008-9214-6.

Taylor, L. F., P. F. Black, D. J. Pitt, A. R. Mackenzie, S. J. Johnson, and B. J. Rodwell. 2006. A seroepidemiological study of bovine pestivirus in Queensland beef and dairy herds conducted in 1994/95. Aust. Vet. J. 84:163-168. https://doi.org/10.1111/j.1751 -0813.2006.tb12771.x.

Tratalos, J. A., D. A. Graham, and S. J. More. 2017. Patterns of calving and young stock movement in Ireland and their implications for BVD serosurveillance. Prev. Vet. Med. 142:30-38. https://doi .org/10.1016/j.prevetmed.2017.04.005.

Tråvén, M., S. Alenius, C. Fossum, and B. Larsson. 1991. Primary bovine viral diarrhoea virus infection in calves following direct contact with a persistently viraemic calf. J. Vet. Med. Series B 38:453-462. https://doi.org/10.1111/j.1439-0450.1991.tb00895.x.

Valle, P. S., S. W. Martin, R. Tremblay, and K. Bateman. 1999. Factors associated with being a bovine-virus diarrhoea (BVD) seropositive dairy herd in the Møre and Romsdal County of Norway. Prev. Vet. Med. 40:165-177. https://doi.org/10.1016/s0167-5877(99)00030-6.

Viechtbauer, W. 2010. Conducting meta-analyses in $\mathrm{R}$ with the metafor package. J. Stat. Softw. 36:1-48. https://doi.org/10.18637/jss .v036.i03.

Viechtbauer, W., and M. W. L. Cheung. 2010. Outlier and influence diagnostics for meta-analysis. Res. Synth. Methods 1:112-125. https://doi.org/10.1002/jrsm.11.

Wentink, G. H., K. Frankena, J. C. Bosch, J. E. D. Vandehoek, and T. Van Den Berg. 2000. Prevention of disease transmission by semen in cattle. Livest. Prod. Sci. 62:207-220. https://doi.org/10.1016/ S0301-6226(99)00158-X.

Williams, D., and S. V. Winden. 2014. Risk factors associated with high bulk milk antibody levels to common pathogens in UK dairies. Vet. Rec. 174:580. https://doi.org/10.1136/vr.102049.

Wittum, T. E., D. M. Grotelueschen, K. V. Brock, W. G. Kvasnicka, J. G. Floyd, C. L. Kelling, and K. G. Odde. 2001. Persistent bovine viral diarrhoea virus infection in US beef herds. Prev. Vet. Med. 49:83-94. https://doi.org/10.1016/s0167-5877(01)00181-7. 